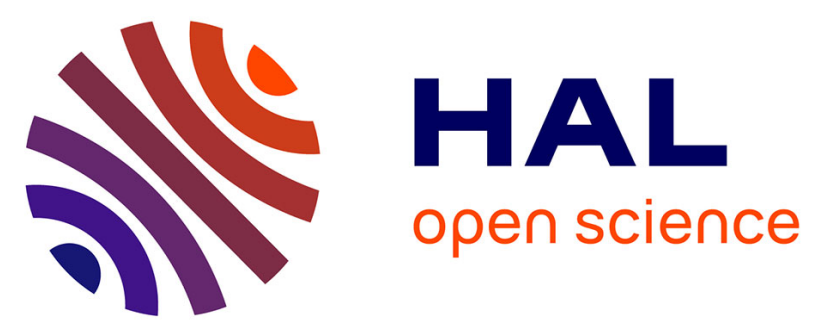

\title{
Firewood and timber collection and management strategies from early medieval sites in eastern england. Initial results from the anthraco-typological analysis of oak charcoal remains
}

Robert Francis, Alexa Dufraisse

\section{To cite this version:}

Robert Francis, Alexa Dufraisse. Firewood and timber collection and management strategies from early medieval sites in eastern england. Initial results from the anthraco-typological analysis of oak charcoal remains. Quaternary International, 2020, 10.1016/j.quaint.2020.10.070 . mnhn-03008091

\section{HAL Id: mnhn-03008091}

\section{https://hal-mnhn.archives-ouvertes.fr/mnhn-03008091}

Submitted on 16 Nov 2020

HAL is a multi-disciplinary open access archive for the deposit and dissemination of scientific research documents, whether they are published or not. The documents may come from teaching and research institutions in France or abroad, or from public or private research centers.
L'archive ouverte pluridisciplinaire HAL, est destinée au dépôt et à la diffusion de documents scientifiques de niveau recherche, publiés ou non, émanant des établissements d'enseignement et de recherche français ou étrangers, des laboratoires publics ou privés. 


\section{Journal Pre-proof}

Firewood and timber collection and management strategies from early medieval sites in eastern england. Initial results from the anthraco-typological analysis of oak charcoal remains

Robert Francis, Alexa Dufraisse

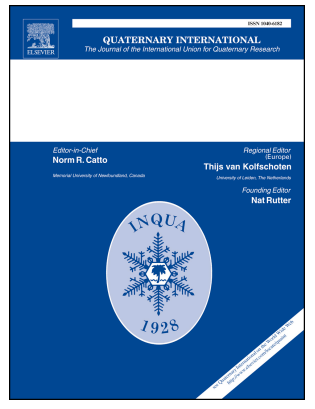

PII:

S1040-6182(20)30716-3

DOI: https://doi.org/10.1016/j.quaint.2020.10.070

Reference: JQI 8615

To appear in: Quaternary International

Received Date: 31 July 2020

Revised Date: 22 October 2020

Accepted Date: 27 October 2020

Please cite this article as: Francis, R., Dufraisse, A., Firewood and timber collection and management strategies from early medieval sites in eastern england. Initial results from the anthraco-typological analysis of oak charcoal remains, Quaternary International (2020), doi: https://doi.org/10.1016/ j.quaint.2020.10.070.

This is a PDF file of an article that has undergone enhancements after acceptance, such as the addition of a cover page and metadata, and formatting for readability, but it is not yet the definitive version of record. This version will undergo additional copyediting, typesetting and review before it is published in its final form, but we are providing this version to give early visibility of the article. Please note that, during the production process, errors may be discovered which could affect the content, and all legal disclaimers that apply to the journal pertain.

(C) 2020 Published by Elsevier Ltd. 
1 Firewood and timber collection and management strategies from early 2 medieval sites in eastern England. Initial results from the anthraco3 typological analysis of oak charcoal remains

4

Robert Francis ${ }^{a}$, Alexa Dufraisse ${ }^{b}$

a Department of Classics and Archaeology, University of Nottingham, University Park, Nottingham, NG7 2RD, United Kingdom

b UMR 7209, Archeozoologie, Archeobotanique: societes, pratiques et environnements CNRS, Museum national d'Histoire naturelle, , CP56, 55 rue Buffon, 75005 Paris, France

\section{Abstract}

The study of charcoal from archaeological sites often focuses on merely the identification of taxa. However, the anthraco-typological analysis of oak charcoal offers extensive evidence about the wood diameter, growth pattern, and minimum age of the trees selected for harvest. This in turn gives valuable data on palaeoecology and woodland management. This review focuses on early stage results from oak charcoal remains from three early medieval rural sites in eastern England, dating from the 5th to the 9th century AD. Over 200 fragments of oak charcoal were selected and examined to identify the size class of the wood, the growth patterns and whether the wood was sapwood or heartwood. This has then given evidence of timber and fuel wood collection strategies and woodland management regimes. The data has provided additional evidence on the nature of the sites' features. Furthermore, the analysis has allowed comparisons to be drawn between the three contemporary sites, as well as to expand the archaeobotanical record to a more detailed understanding of the environment around these settlements. Exceptional material from the early medieval site of Flixborough has allowed a unique insight into the selection of timber and possible long-term woodland management strategies undertaken in the area during the mid 8th to 9th century AD. The results will be discussed regarding the economic and environmental context, demonstrating the value of dendro-anthracological tools in adding additional detail and a new understanding of these sites.

KEY WORDS: Wood Charcoal, Wood Diameter, Radial Growth, Sapwood/Heartwood, Dendro-anthracology 
42

43 Woodlands are not a static feature of the landscape. They have always been 44 considered a commodity and exploited according to the needs of the community. 45 Changes in the needs of the population due to various factors such as 46 demographic pressures may cause the management strategies to change, for 47 example from managed harvesting to the clearing of ground for arable land 48 (Haneca et al., 2009). By the early medieval period Britain is described as 49 having lost most, if not all, of its wild wood, with most of the cultivatable land being given over to agriculture and the remaining land being heath and moorland (Rackham, 1994). Woodland usually represents managed naturally grown trees clustered in 'islands' amongst farmland. The term forest is not used in this article so as to avoid confusion with the medieval use of the term 'Forest'; a place for keeping and hunting deer (Rackham 2006: 24-27). During the early medieval period there were areas of Britain which had little or no woodland (Hooke, 2010: 120). By the end of this period the Domesday book records the county of Lincolnshire (the county in which Flixborough is situated) as only having $4 \%$ of its area covered by woodland and Northamptonshire (the county in which Dando Close and Higham Ferrers are situated) as having $8.8 \%$ of its area covered by woodland (Rackham, 1995: 54).

Palynology and anthracology are common proxies used to reconstruct woodland environments (Haneca, 2005). Evidence for the state of Britain's woodlands during the early medieval period is heavily reliant on pollen evidence. Although post Roman abandonment of managed woodlands and the reforesting of cultivated areas has often been suggested, the pollen evidence only supports this for some areas in the north west and north of England between AD 400-800 68 (Dark, 2000:156) and (Huntley, 2010:31). This in turn highlights the problem with relying on pollen evidence as most sites are primarily located either in the western and northern edges of Britain, or in the southeast (Gearey and Richer, 
2017). The sites under analysis here are situated in the East of Britain and do

72 not have relative pollen data.

73 Alternatively, anthracological analysis of assemblages can provide an

74 assessment of the wood harvested for domestic and industrial purposes. The analysis of charcoal differs from a pollen reconstruction as it is normally a result of human interaction with the environment during the period under investigation and therefore represents the past vegetation and how the inhabitants interacted with it (Asouti and Austin, 2005). Unfortunately, the number of anthracological assessments from the early medieval period in Britain is scarce in comparison to the preceding Roman period (Smith 2002, Murphy et al., 2001 and Huntley, 2010). Assessments that include interpretations relating to the age, size, and possible woodland management strategies are particularly limited. There are however examples of evidence of wood selection recorded and interpreted by anthracologists. Robinson's (1997) analysis at Clacket Lane, Surrey, concluded that mature slow growing oak branch wood (identified by the presence of tyloses) was being selected for pottery furnaces. Another example is the Saxon pottery kiln at Michelmersh, Hampshire where Gale (2007) identifies the maturity of oak wood by assessing the presence of heartwood versus sapwood and stem diameters. Hall and Kenward (2004: 412) discuss the local woodland management around medieval York by interpreting the number of growth rings present in willow and hazel rods recovered from urban deposits. These three examples rely on the presence of round wood to identify age as well as the presence of tyloses to indicate heartwood in oak.

More recent studies have seen the adoption of anthracological approaches from continental Europe. Crew and Mighall's (2013) assessment of a medieval bloomery in Snowdonia calculates the estimated diameter of the charcoal fragments following Nelle's (2002) and Ludemann's (2008) diameter stencil method. This has allowed them to interpret the woodland management strategies at the site. Additionally, the study by Hazel et al. (2017) of charcoal

100 from the post-medieval charcoal burning platforms at Barbon, Cumbria, uses an 101 array of measurements based on methodology set out by Marguerie and Hunot 102 (2007), including the number of growth rings, a qualitive assessment of the ring 103 curvature, the presence of pith, bark, reaction wood, tyloses, degradation, radial 104 fractures and vitrification level. 
105 As of yet no study in Britain has used a quantitative combination approach

106 following those set out in this article, making this initial study unique in Britain.

107 Oak is a preferred timber tree because of its durability and mechanical

108 properties and can be found in the construction of castles, cathedrals as well as

109 domestic buildings (Haneca et al., 2009). Oak also responds well to coppice and

110 pollarding (Rackham, 1995: 8). The ubiquitous presence of oak charcoal in

111 archaeological assemblages from the early medieval period, (Smith, 2002,

112 Murphy et al., 2001 and Huntley, 2010) make it the ideal genus for dendro-

113 anthracological analysis. This research represents the innovative application of

114 dendro-anthracological tools to archaeological assemblages rich in oak charcoal.

115 For the first time this methodology has been applied to three sites in early

116 medieval eastern England.

117 The objectives of the dendro-anthracological analysis were to:

118 (i) identify wood collection strategies, including the tree's estimated minimum

119 diameter and what parts of the tree were being exploited.

120 (ii) identify the growth rate and potential age range of the trees being 121 harvested.

122 (iii) inter-site and temporal comparisons of the size, growth rate and what part 123 of the trees were being used.

124 (iv) identify evidence of possible woodland management or climatic and 125 environmental impacts on the growth of the trees.

\section{Regional setting}

127

128 Charcoal from samples not previously examined were chosen from three early

129 medieval sites in eastern England (Fig. 1). The sites of Dando Close, and Higham

130 Ferrers are in the county of Northamptonshire, and the site of Flixborough is in

131 Lincolnshire, England. 


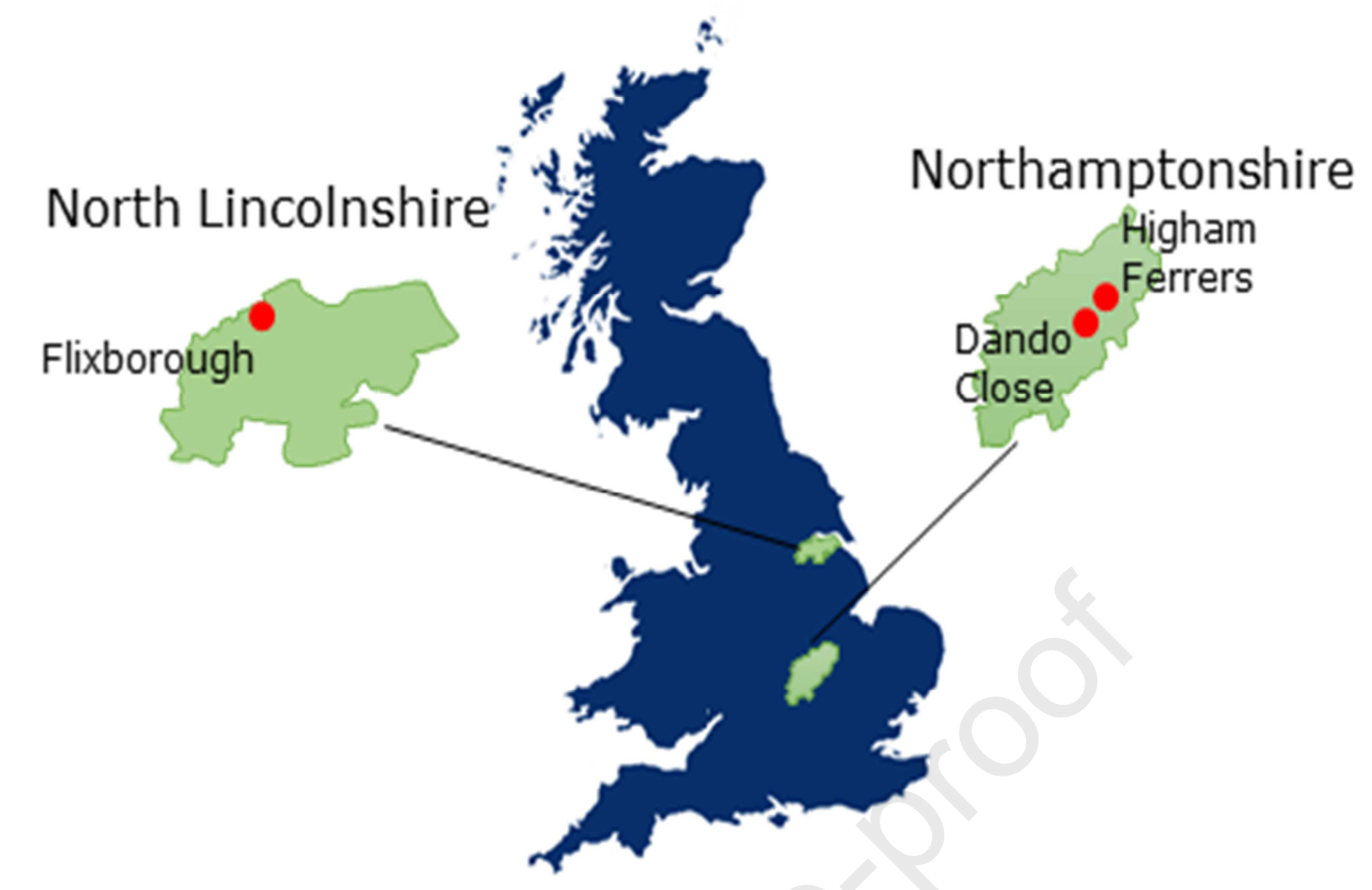

Fig. 1. Location of the three study sites.

136 The site of Dando Close is situated in the village of Wollaston on a ridge of

137 limestone overlooking the alluvial plain of the Nene Valley, $5 \mathrm{~km}$ east of the 138 River Nene (British Geological Survey, 2020). The area has a temperate oceanic 139 climate with an average rainfall of between 500 and $750 \mathrm{~mm}$ annually. The 140 average summer temperature is between 14.8 and $15.8{ }^{\circ} \mathrm{C}$ and the average 141 winter temperature is between 3.8 and $4.2{ }^{\circ} \mathrm{C}$. (Met Office, 2020). Approximately $1425.2 \%$ of the county is covered in woodland (compared to $10 \%$ nationally). 57\% 143 of this is broadleaved and $43 \%$ is coniferous or mixed scrubland species 144 (Northamptonshire County Council 2020). The village of Wollaston has limited 145 woodland with 3.35 hectares of small plots of broadleaved woodlands within 2 $146 \mathrm{~km}$ of the site (Forestry Commission 2020).

147 Heritage Network Ltd undertook the excavations at Dando Close, between 2000 148 and 2002. The excavation revealed an early medieval settlement with remains 149 dating from the 5th to the 14th centuries AD (Semmelmann and Ashworth 2003: 150 2). The contexts sampled included, fills of post-holes, fills of an oven, fills of 151 sunken feature buildings, and fills of hearths. 
153 The site of Higham Ferrers is situated in the town of the same name on a ridge

154 of limestone on the eastern bank of the River Nene. The surrounding occupation

155 area includes alluvial plains and a Boulder Clay plateau (British Geological

156 Survey). The area has a temperate oceanic climate with an average rainfall of

157 between 500 and $750 \mathrm{~mm}$ annually. The average summer temperature is

158 between 14.8 and $15.8{ }^{\circ} \mathrm{C}$ and the average winter temperature is between 3.8

159 and $4.2^{\circ} \mathrm{C}$. (Met Office, 2020). The town of Higham Ferrers has limited woodland

160 with 9.72 hectares of small plots of broadleaved woodlands within $2 \mathrm{~km}$ of the

161 site, most of which is situated in the nearby Nene Valley (Forestry Commission

162 2020).

163 The Oxford Archaeological Unit excavated the site between 1993 and 2003 164 (Hardy et al., 2007). The excavation uncovered a rural settlement with 165 continuous occupation from the Roman to the medieval period, including a large 166 8th century AD enclosure and associated buildings. Sampled contexts included 167 the fill of pits, the fill of sunken feature buildings and residues from a malting 168 oven.

170 The site of Flixborough, North Lincolnshire is situated on a series of windblown 171 sand spurs $8 \mathrm{~km}$ south of the Humber estuary. The site overlooks the floodplain 172 of the River Trent (Loveluck, 2007: 3). The area has a temperate oceanic 173 climate with an average rainfall of between 560 and $660 \mathrm{~mm}$ annually. The 174 average summer temperature is between 14.8 and $15.8{ }^{\circ} \mathrm{C}$ and the average 175 winter temperature is between 3.8 and $4.2{ }^{\circ} \mathrm{C}$ (Met Office, 2020). Just over $4 \%$ 176 of Lincolnshire is covered by woodland, making it one of the least wooded 177 counties in Britain. $57.5 \%$ of this is broadleaved and $42.5 \%$ is coniferous or 178 mixed scrubland species (Collop, 2011). The area around the village has 179 approximately 55.21 hectares of mainly broadleaved woodland within $2 \mathrm{~km}$ of 180 the site (Forestry Commission, 2020).

181 The excavation was conducted by Humberside Archaeology Unit between 1989 182 and 1991 and funded on behalf of English Heritage. The excavation uncovered 183 the remains of an early medieval settlement, including over thirty buildings 184 dating from the early $7^{\text {th }}$ to the mid $14^{\text {th }}$ centuries AD. Also uncovered were well 185 preserved refuse deposits containing large quantities of artefacts, faunal remains 
and charcoal, sealed by windblown sand (Loveluck, 2007: 8). The charcoal

187 remains from the site were exceptionally well preserved with many large

188 fragments, some of which show carpenter tool marks (Loveluck and Darrah

189 2007: 57).

191 This study focuses on the early medieval period between the $5^{\text {th }}$ and $10^{\text {th }}$ 192 centuries. (Fig. 2). Dating for the sites was based on stratigraphic, artefactual 193 and scientific dating where possible (Hardy et al., 2007: 13, Semmelmann and 194 Ashworth, 2003: 29), and (Loveluck, 2007: 8-30).

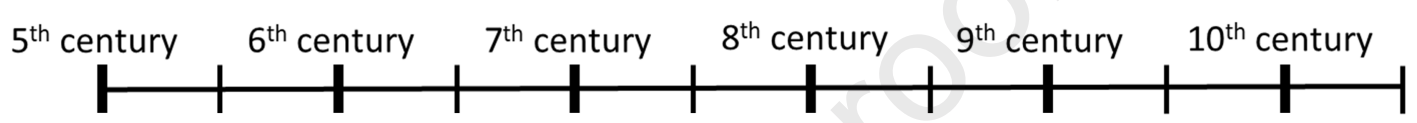

\section{Dando Close}

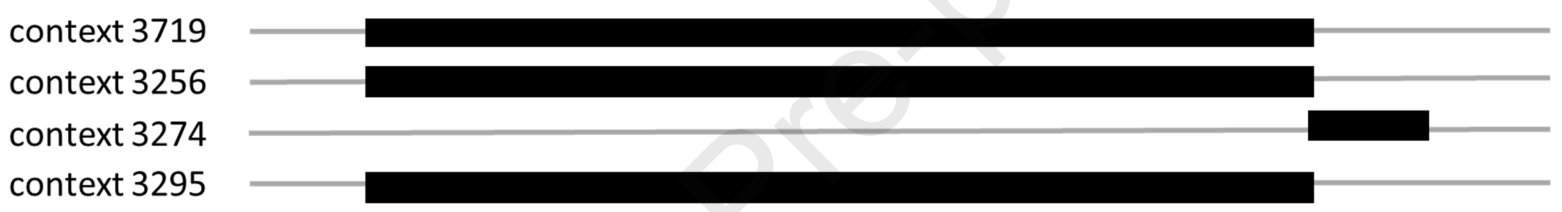

\section{Higham Ferrers}

context 2644

context 4037

\section{Flixborough}

context 6136

context 3758

Fig. 2. Chronology for the samples analysed.

201 Sample selection was based on three criteria. Firstly, the date of the samples were selected to be similar across the three sites. This would allow comparisons

203 to be drawn between the sites. Secondly, samples were selected from contexts 204 of interest, such as domestic refuse deposits and specialised structures, like that 205 of the malting oven at Higham Ferrers. This criteria allowed short and long term 206 deposits to be sampled, with long term deposits likely to give information on the 207 diversity of the vegetation and short term deposits more likely to represent specific composition of the last firing event (Chabal et al., 1999: 61). Finally, 
samples with an abundance of large oak fragments were selected. This would optimise the chances of enough suitable fragments being available for dendro-

211 anthracological assessment.

\section{3.1.1. Dando Close}

214 A bulk sampling strategy was adopted for the site whereby all dateable features 215 were sampled. As a result, 714 bulk samples were taken for analysis. The bulk 216 samples were sent to Environmental Archaeology Consultancy to be processed 217 using a Siraf flotation tank fitted with a $0.5 \mathrm{~mm}$ sieve to collect the light fraction 218 and a $1 \mathrm{~mm}$ mesh to collect the heavy residue. Once the flots were dry the 219 heavy residue was refloated to create a second light fraction allowing for the 220 recovery of additional charred material that could have been potentially still

221 trapped in the sediment.

222 Environmental Archaeology Consultancy loaned 41 unanalysed light fraction 223 samples for the author's PhD research project. Of these, four samples were 224 selected for this dendro-anthracology study.

225 The sample from context 3295 (mid $5^{\text {th }}$ to mid $9^{\text {th }}$ century AD) comes from the 226 fill of a post hole from a sunken feature building.

227 The sample from context 3256 (mid $5^{\text {th }}$ to mid $9^{\text {th }}$ century AD) comes from a 228 post hole not associated with any buildings containing a large amount of 229 charcoal consisting nearly exclusively of oak.

230 The sample from context 3719 (mid $5^{\text {th }}$ to mid $9^{\text {th }}$ century AD) comes from a 231 hearth containing a large amount of oak charcoal.

232 The sample from context 3274 (mid $9^{\text {th }}$ to $10^{\text {th }}$ century AD) comes from the fill of 233 a post-hole believed to be from a burnt down grain store due to the large 234 amount of grain found in the post holes. It was postulated that the grain relates 235 to a single burning incident (Rackham, 2003).

\section{3.1.2. Higham Ferrers}

238 Oxford Archaeology undertook the environmental sample processing at Higham 239 Ferrers. Bulk samples were taken at the discretion of the excavator and in 240 consultation with the archaeobotanist. Occupation material, as well as context 241 deemed of interest were sampled. 94 samples in total were collected. 42 242 samples were processed by Siraf flotation using a $0.25 \mathrm{~mm}$ sieve to collect the 243 light fraction and a $1 \mathrm{~mm}$ mesh to collect the heavy residue. The Oxford 
244 Archaeological Unit loaned five unanalysed charcoal samples from the published

245 site of Higham Ferrers, two of which were selected for this study.

247 The sample from context 2644 (early to late $8^{\text {th }}$ century AD) comes from the fill 248 of a post-pipe located in a dwelling. The material is believed to be domestic in 249 origin or from grain processing.

250 The sample from context 4037 (late $8^{\text {th }}$ to early $9^{\text {th }}$ century AD) comes from the 251 bottom of a flue in a stone built malting oven. The botanical remains were rich in 252 barley, a proportion of which showed signs of sprouting (Moffett, 2007).

\section{3.1.3. Flixborough}

255 Humberside Archaeology Unit undertook the environmental sampling at 256 Flixborough. 560 samples and sub-samples from 386 contexts were taken. Due 257 to the exceptional preservation of the charcoal in the refuse deposits, it was collected on site as spot finds to avoid mechanical damage (Hall, 2000). The North Lincolnshire Museum archive loaned nine samples of hand-collected charcoal from excavated contexts of which two were selected for this study. The sample from context 6136 (mid $8^{\text {th }}$ to early $9^{\text {th }}$ century AD) and the sample from context 3758 ( $\mathrm{mid} 9^{\text {th }}$ century AD) both come from large waste dumps in a shallow valley. The contents of which are believed to be the result of rebuilding or the demolition of structures on the site.

\subsection{Methods}

\section{3.2.1. Anthracology method}

268 The anthracological analysis of the charcoal followed Chabal et al. (1999: 66-67) recommendations, that to recover the full range of taxa in an assemblage it is necessary to establish a fragment/taxa curve until a plateau is reached.

271 For each sample a minimum of 100 fragments were analysed. The charcoal was

272 graded into $>4 \mathrm{~mm}$ and $2-4 \mathrm{~mm}$ fractions and all fragments were then analysed.

273 Fragments were fractured following standard methods of preparation (Leney and

274 Casteel, 1975). The fragments were fractured so as the transverse section could 275 be observed using a low power stereomicroscope at x10-40 magnification, 276 allowing the growth rings to be examined and counted. The fragments were then 277 fractured in all three sections (transverse, tangential longitudinal and radial 278 longitudinal) and observed using an epi-illuminating microscope at 
magnifications of $\times 100-500$, so as the key features could be recorded. The

280 anatomy of the fragment was then compared with published sources (Hather,

281 2000; Schweingruber, 1982) and with the modern charcoal sample from a

282 reference collection available at the Department of Classics and Archaeology of

283 the University of Nottingham. Identification to genus level was usually possible,

284 however trees and shrubs belonging to the apple subfamily (Maloideae)

285 including hawthorn (Crataegus), apple (Malus), pear (Pyrus) and mountain

286 ash/service (Sorbus) are notoriously difficult to identify to genus and therefore

287 were labelled as Maloideae. It is often difficult to distinguish between willow

288 (Salix sp.) from popular (Populus sp.) based on their wood anatomy. The

289 distinguishing feature used here are the predominance of heterogeneous rays 290 visible in the radial section of willow. Popular has a predominance of 291 homogeneous rays. Where the rays were not visible or there was not a 292 predominance of either heterogeneous or homogeneous rays the label of 293 popular/willow was given to the fragment (Hather 2000: 111). Oak fragments 294 were identified as Quercus dec. (deciduous oak) as anatomically the two species 295 of common deciduous oak pedunculate (Quercus robur L.) and sessile oak 296 (Quercus petraea (Matt.) Liebl.) cannot be differentiated based on their wood 297 anatomy. Charcoal fragments of oak that had a $2 \mathrm{~mm}$ or greater transverse 298 cross section and at least one entire growth ring including both boundaries were 299 separated for further dendro-anthracological analysis.

\subsubsection{Dendro-anthracological method}

302 Oak provides clearly identifiable anatomy, such as growth rings and ligneous 303 rays which facilitate measurements as well as the ability to identify the 304 lignification process where heartwood is created. Fragments of oak charcoal 305 were observed using a Nikon AZ100 multizoom microscope with magnification 306 factors of $x 4$ to $x 500$ and NIS Element image analysis software based at the 307 UMR 7209 (MNHN/CNRS, Paris) according to the protocol defined by Dufraisse et 308 al. (2018a).

309 At its core, dendro-anthracology aims by means of several different tools to 310 identify where in the tree the fragment of charcoal originated in respect of the 311 centre of the stem, thus allowing the growth rate and the diameter of wood 312 harvested to be calculated (Dufraisse et al., 2018a). Firstly, the fragment is 313 assessed as to whether it shows the presence of sapwood or heartwood, this is 
314 achieved by calculating the ratio of tyloses filled vessels versus empty vessels.

315 Up to 50 vessels spread over 3-4 rings are counted. If over $85 \%$ of the vessels

316 have tyloses, the fragment is considered to be heartwood. Those fragments

317 where less than $65 \%$ of the vessels have tyloses are recorded as sapwood. This

318 measurement estimates the minimum age range of the wood, as heartwood

319 generally forms in oak wood after 20 to 25 years (Dufraisse et al. 2018b).

320 Secondly, the pith estimation tool. This calculates an estimated minimum radius

321 for the charcoal fragment being studied. This is done by measuring the radius of

322 the fragment from the outermost complete growth ring using a trigonometric

323 tool to measure the angle and the distance between two ligneous rays (Dufraisse

324 et al., 2020). The measurement is repeated five times and the average is

325 calculated after removing the two extreme values. The radius value then gives a

326 projected diameter (radius $\times 2$ ) and is grouped in diameter classes according to

327 Dufraisse et al. (2018a) 0-2 cm, 2-4 cm, 4-7 cm, 7-10 cm 10-20 cm, and >20

$328 \mathrm{~cm}$. Finally, the growth rings of each fragment are measured to the nearest 0.01

$329 \mathrm{~mm}$ and the average calculated for the fragment. A threshold of $1.5 \mathrm{~mm}$ is used

330 to differentiate narrow from wide rings. Additionally, the growth pattern of

331 fragments with multiple rings was recorded. The measured width for the growth

332 ring has a correction of an additional $20 \%$ applied to compensate for the

333 shrinkage effect while being transformed from wood to charcoal. This is based

334 on experimental work carried out by Paradis-Grenouillet and Dufraisse (2018)

335 where oak wood underwent carbonization (heating without oxygen as described

336 by Braadbaart and Poole (2008)) and the reduction in size was measured. The

337 combination of these parameters makes it possible to arrange each fragment

338 into 8 anthraco-groups (Fig. 3). The first division separates the fragments into

339 less or greater than $7 \mathrm{~cm}$ diameter and relates to the limit between branches

340 and trunks in deciduous oak woodlands. The next division combines specific

341 threshold values between sapwood and heartwood and narrow and large rings

342 (Dufraisse et al., 2018a). 


\section{ANTHRACO-TYPOLOGICAL GRID}

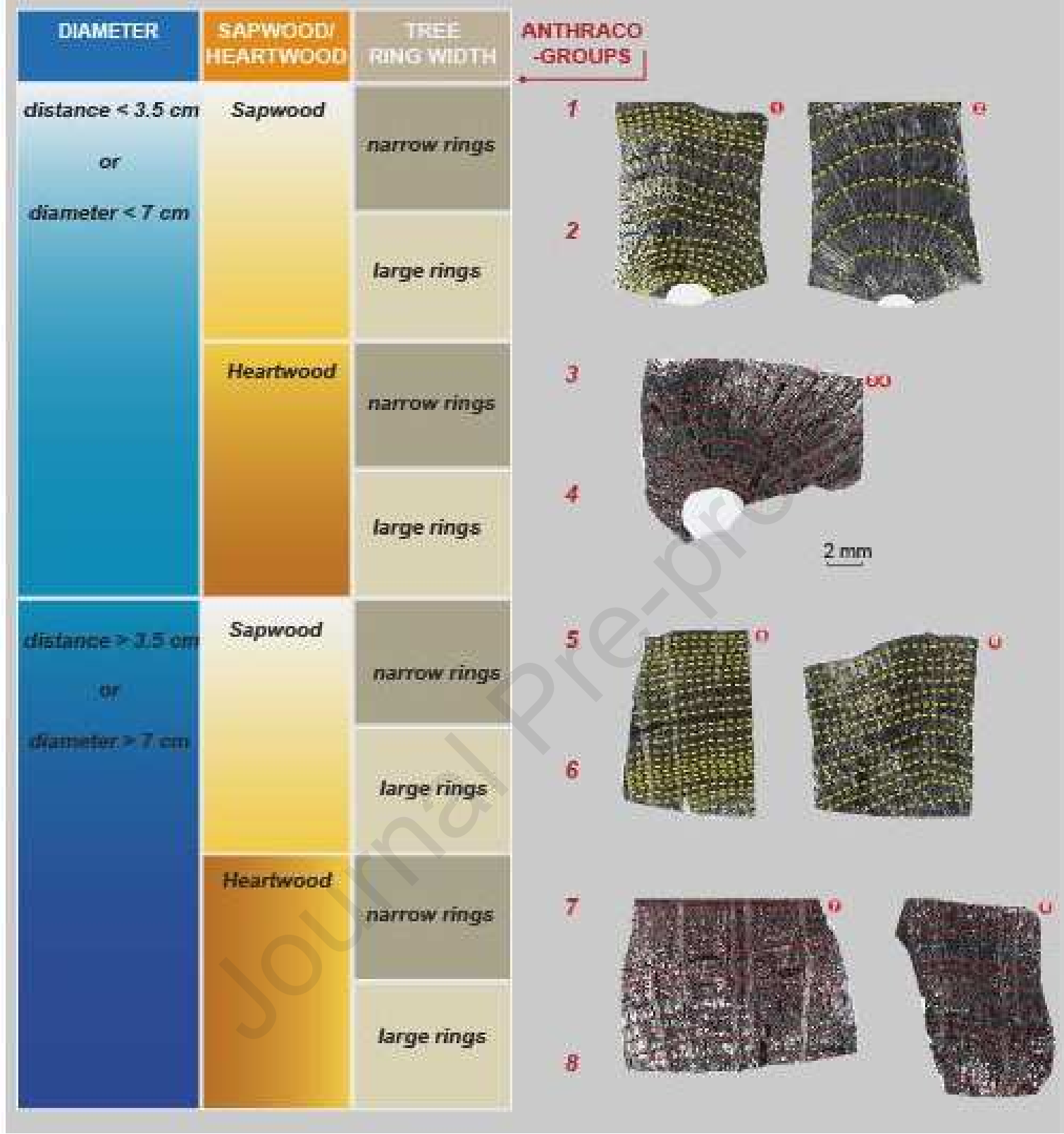

Fig. 3. Anthraco-typological grid, from Dufraisse et al., 2018a

350 4. Results

351 4.1. Anthracological results

352 Eight samples from the three research sites were analysed (Fig. 4). 1160 353 fragments were identified. The presence of eight taxa were recorded, those of 354 oak (Quercus dec.), ash (Fraxinus excelsior), hazel (Corylus avellana), field 355 maple (Acer campestre), birch (Betula sp.), alder (Alnus glutinosa), willow (Salix 356 sp.) popular/willow (Populus/Salix sp.) and Maloideae. All the samples contained 357 a majority of oak fragments ranging from $60 \%$ to $100 \%$ with the next most 358 abundant taxa being hazel and ash. These findings are comparable with the 
359 diversity of species already identified from Higham Ferrers (Thompson and 360 Francis, 2007), Flixborough (Hall, 2000) and from the samples analysed by the 361 author from Dando Close (Francis, unpublished).

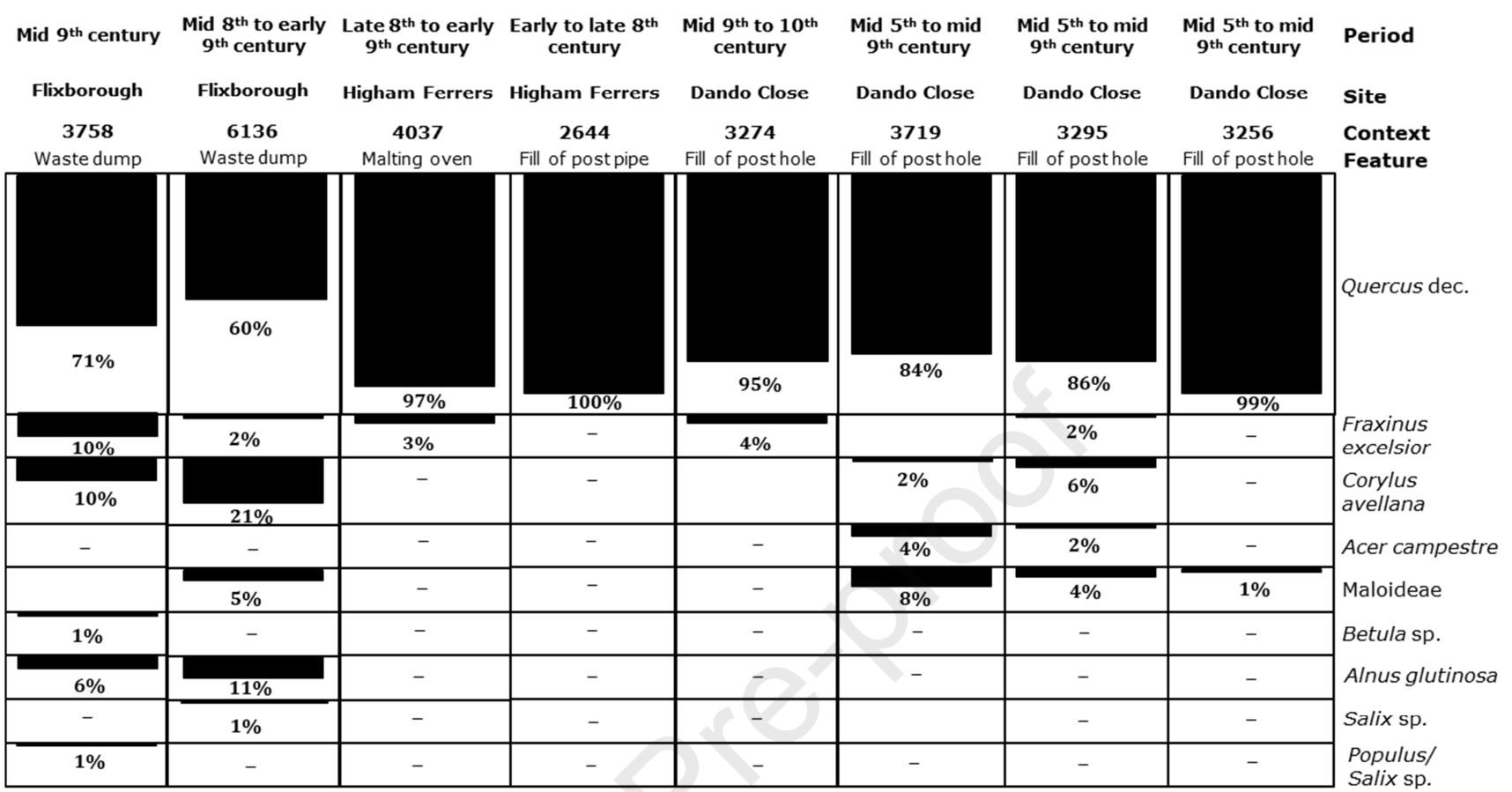

Fig. 4. Anthracological results from the sites of Dando Close, Higham Ferrers and Flixborough

\subsection{Dendro-anthracological results}

366 Following the methodology highlighted above, 283 fragments of oak charcoal 367 were analysed. 1370 annual growth rings were measured, with an average of 368 nearly 5 rings per fragment, although exceptional fragments from the 369 Flixborough site had up to 39 rings present. The wood's estimated diameter, 370 sapwood/heartwood and annual growth rate will first be described. Following this 371 the combination of these results will be detailed in terms of anthraco-groups.

\section{4.2.1. Dando Close}

374 4.2.1.1. Wood diameter

375 The diameter range at Dando Close varies between $0-2 \mathrm{~cm}$ and $10-20 \mathrm{~cm}$ with 376 the highest number of fragments (32.7\%) belonging to class $4-7 \mathrm{~cm}$ followed by 377 classes $2-4$ and $7-10 \mathrm{~cm}$. The least represented class is $0-2 \mathrm{~cm}$. The distribution 378 of wood diameter is not the same from one context to another. Thus, the 379 fragments of between $4-7 \mathrm{~cm}$ are the main class in context 3256, while those 380 between $7-10 \mathrm{~cm}$ dominate context 3295. Fragments of between $2-4 \mathrm{~cm}$ are 
381 highest in context 3274 and those between $10-20 \mathrm{~cm}$ are highest in context 3823719 (Fig. $5 \& 6$ ).

383
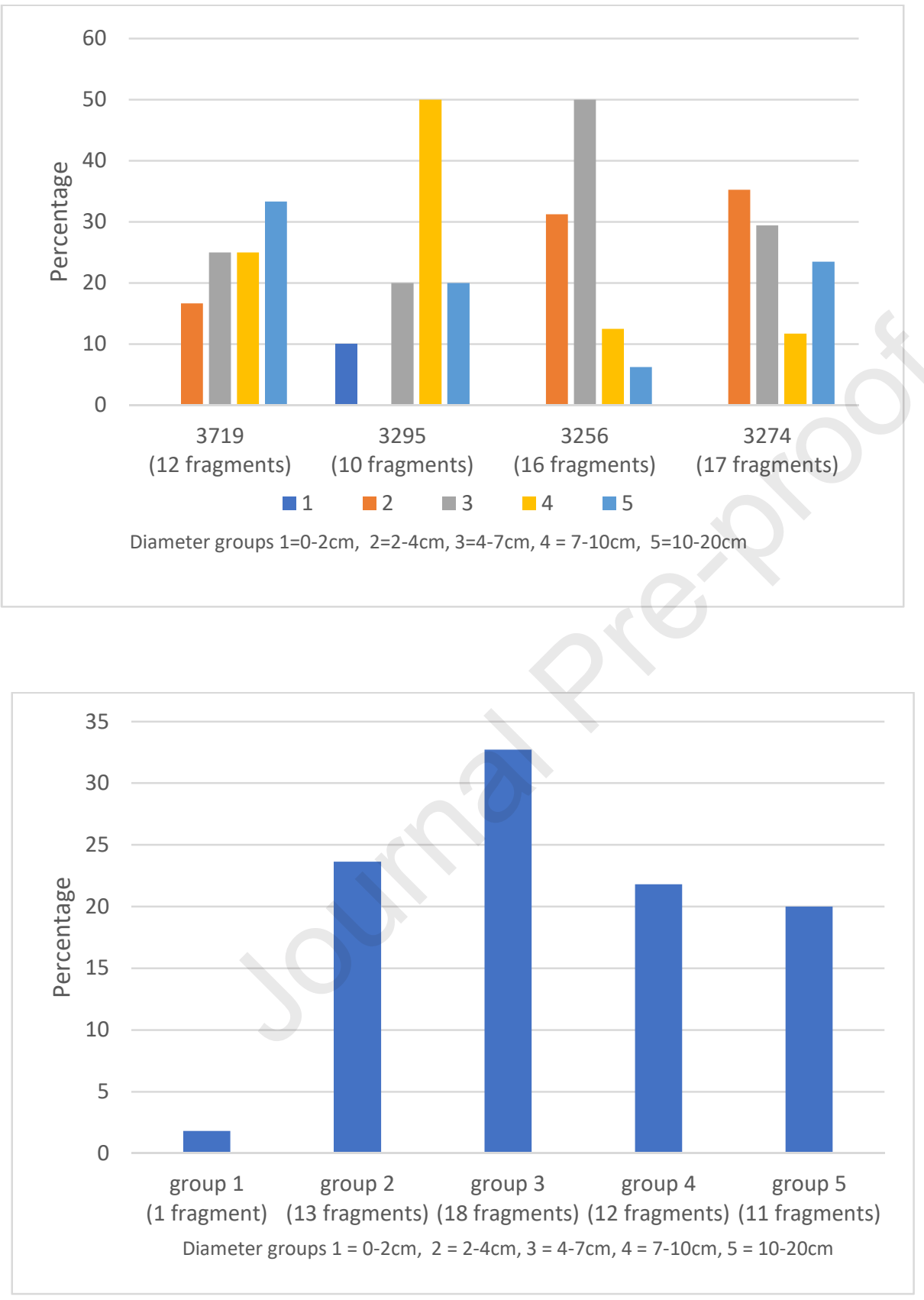

387 Fig.5. Charcoal fragments in percentages by context and 388 diameter group.

389 Fig. 6. Charcoal fragments in percentages for the site overall by 390 diameter group.

4.2.1.2. Sapwood vs Heartwood

$39396 \%$ of the fragments in the assemblage were identified as sapwood (Fig. 7). 394 The assemblage contained only three fragments of heartwood, although these 395 do not appear in the anthraco-typological analysis as they did not provide a pith 
396 estimation value. The three fragments of heartwood present are found in context

3973719,3295 and 3256.

398 4.2.1.3. Annual growth

399 The annual growth range for the site is between $0.77 \mathrm{~mm}$ and $3.85 \mathrm{~mm}$ with an 400 average of $2.04 \mathrm{~mm}$. The sample from context 3719 has a significantly higher 401 average annual growth of $2.5 \mathrm{~mm}$ compared to that of the samples from context 4023295 with $1.66 \mathrm{~mm}$, context 3256 with $2 \mathrm{~mm}$, and context 3274 with $1.93 \mathrm{~mm}$ 403 (Fig 8.).

404

405

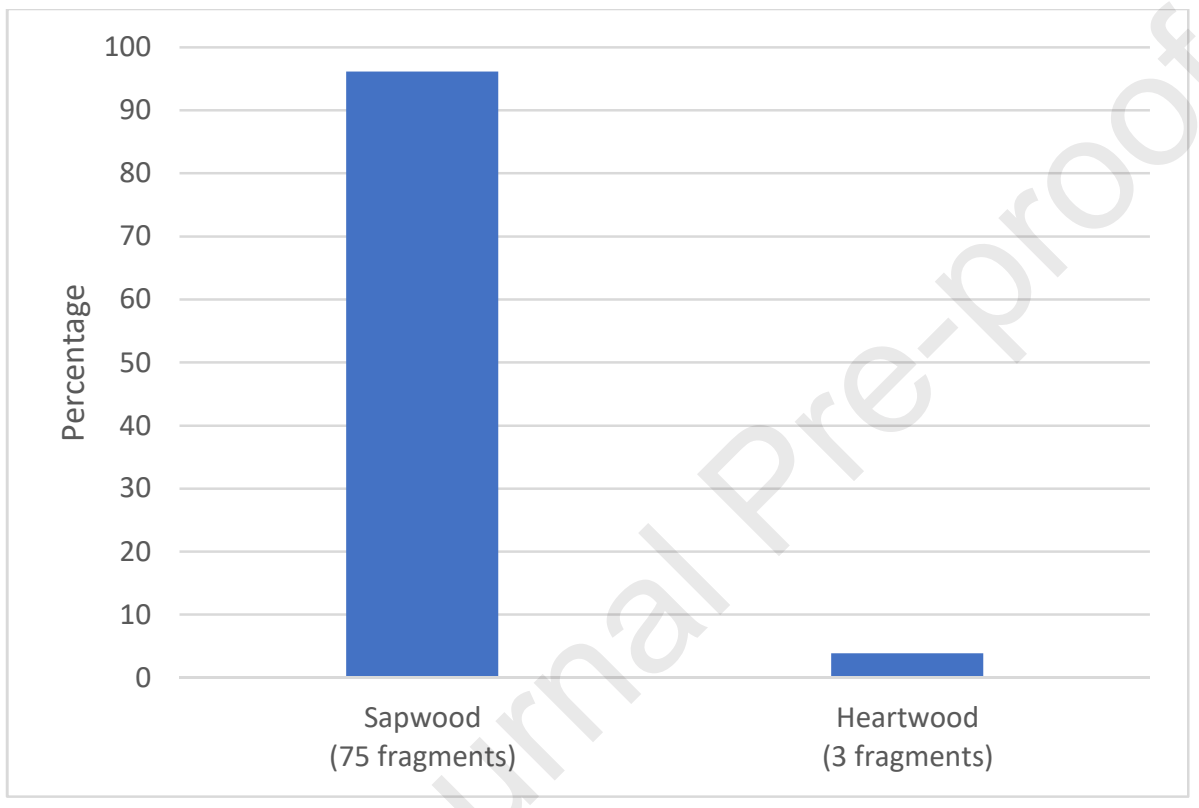

406

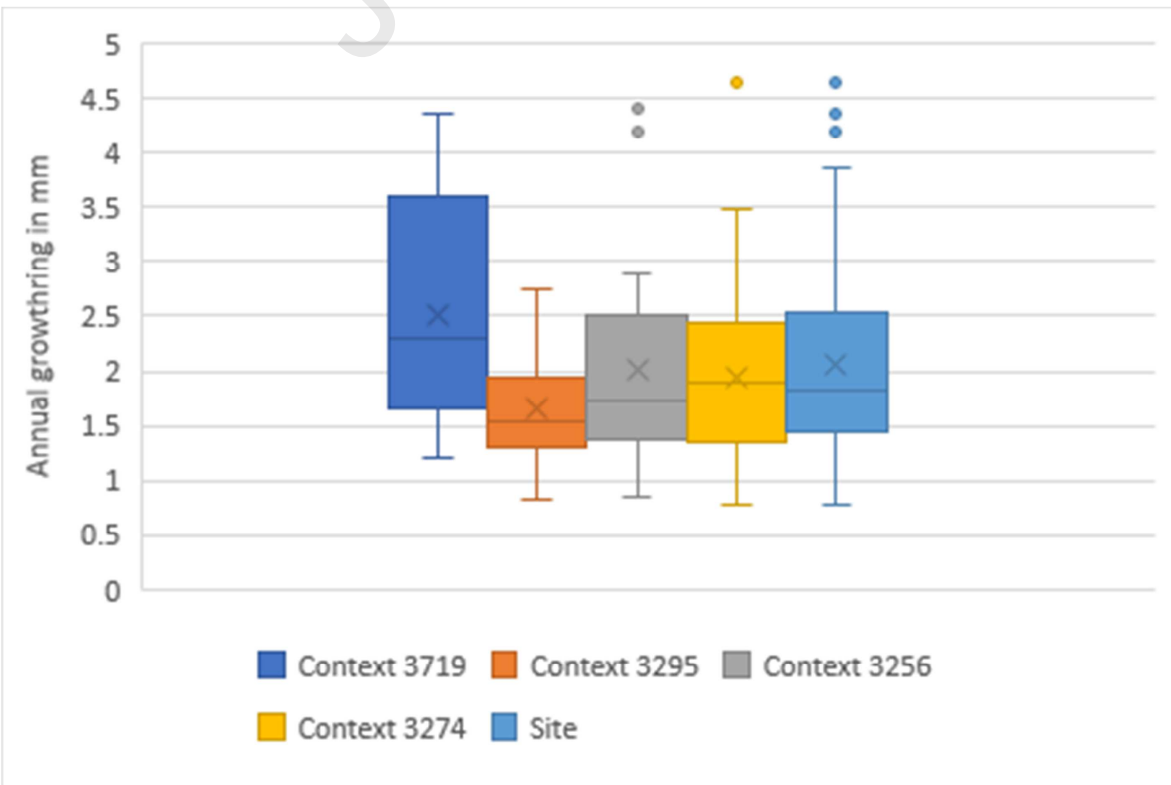

408 Fig. 7. Distribution of charcoal fragments by sapwood and heartwood.

409 Fig. 8. Annual growth ring range by context and for the site. 
4.2.1. 4. Anthraco-typological analysis

412 The charcoal was sorted between eight anthraco-groups according to the results

413 of the dendro-anthracological tool measurements (Fig.9.).

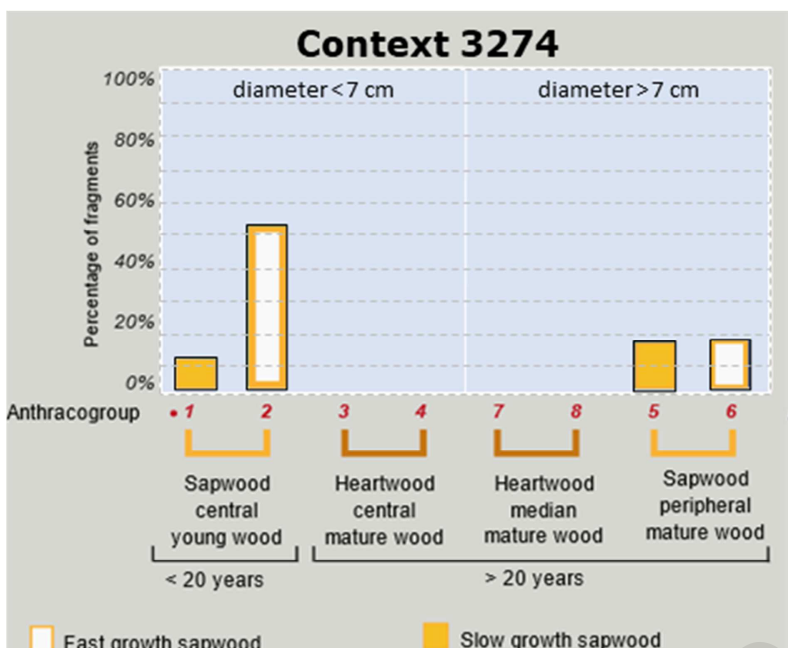

Fast growth sapwood

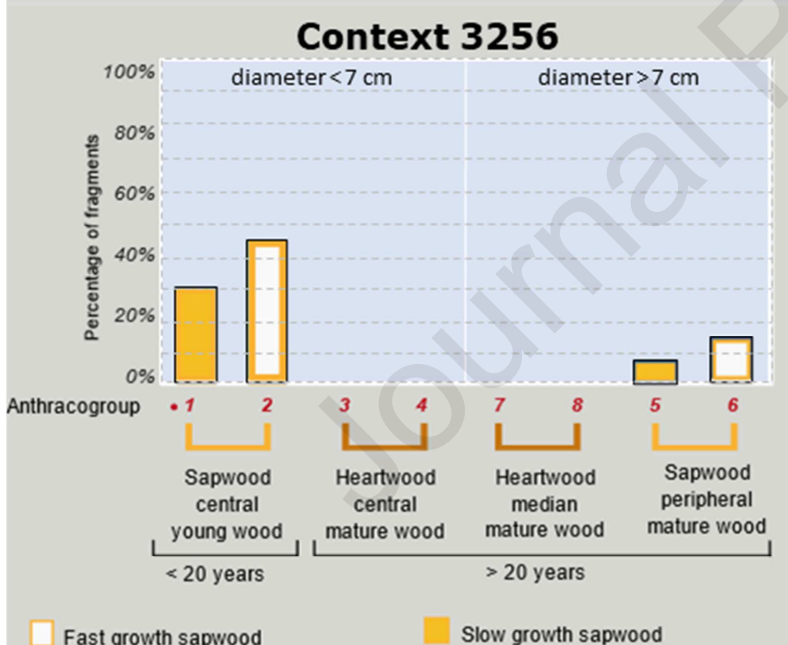

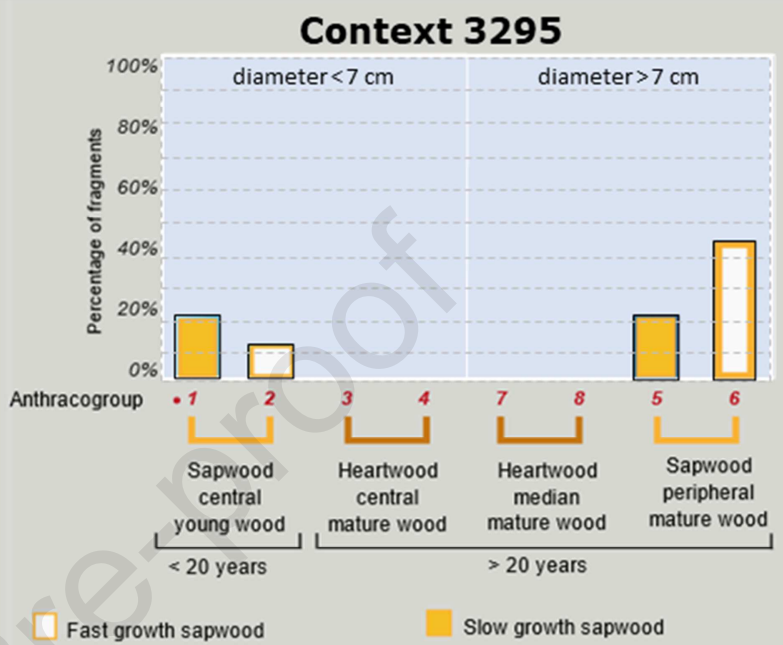

\section{Context 3719}

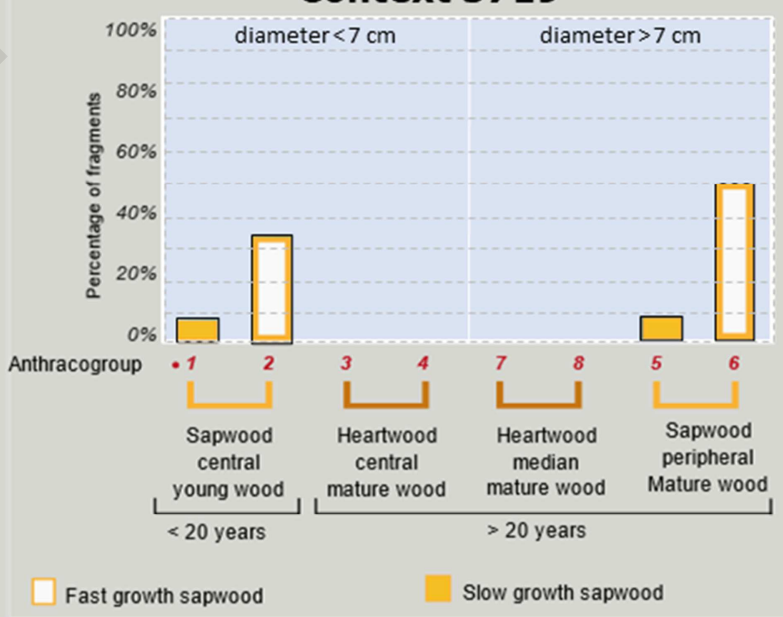

417 Fig. 9. Dendro-anthracological key for the oak from Dando Close sorted into anthraco-groups

419 There are very few differences noticeable between the contexts analysed (SM1).

420 The combination of these three parameters indicates that at a site-wide level, 421 there is exploitation of fast growing sapwood from young and mature trees 422 (anthraco-groups 2 and 6) representing 68.6\% of the assemblage. Group 2's 423 average diameter for the site was $3.92 \mathrm{~cm}$, its maximum diameter was $6.84 \mathrm{~cm}$ 424 and its average annual growth rate was $2.28 \mathrm{~mm}$. Group 6's average diameter 425 was $10.29 \mathrm{~cm}$ and maximum diameter was $17.35 \mathrm{~cm}$ and its average annual 
426 growth rate was $2.19 \mathrm{~mm}$. Fragments from group 2 represent young wood of 427 less than 20 years old. The fragments from group 6 represent sapwood from 428 trunks over 20 years old, however the heartwood that would be expected to 429 show in groups 3, 4, 7 and 8 are not present in the assemblage.

430 There is also the exploitation of slow growing sapwood close to the pith

431 (anthraco-group 1). This potentially corresponds to branch wood representing $43217.64 \%$ of the sampled fragments with an average growth of $1.25 \mathrm{~mm}$ a year. 433 The average diameter for anthraco-group 1 was $5.29 \mathrm{~cm}$ and its maximum was $434 \quad 6.77 \mathrm{~cm}$.

435 The smallest amount of fragments belong to anthraco-group $5(13.72 \%)$. This is 436 slow growing sapwood from the periphery of mature wood. Group 5's average 437 diameter was $12.05 \mathrm{~cm}$ and maximum diameter was $18.71 \mathrm{~cm}$ and its average 438 annual growth rate of $1.17 \mathrm{~mm}$.

439

440 4.2.2. Higham Ferrers

441 4.2.2.1. Wood diameter

442 The diameter range at Higham Ferrers varies between $2-4 \mathrm{~cm}$ and $>20 \mathrm{~cm}$ with 443 the highest number of fragments (32\%) belonging to the diameter class 10-20 $444 \mathrm{~cm}$ followed by classes $4-7 \mathrm{~cm}$ and $7-10 \mathrm{~cm}$. The least represented class is $>20$ $445 \mathrm{~cm}$. The distribution of diameter classes is not the same from one context to the 446 other. The class $4-7 \mathrm{~cm}$ dominates in context 4037, while the class $10-20 \mathrm{~cm}$ 447 dominates in context 2644 (Fig. $10 \& 11$ ).

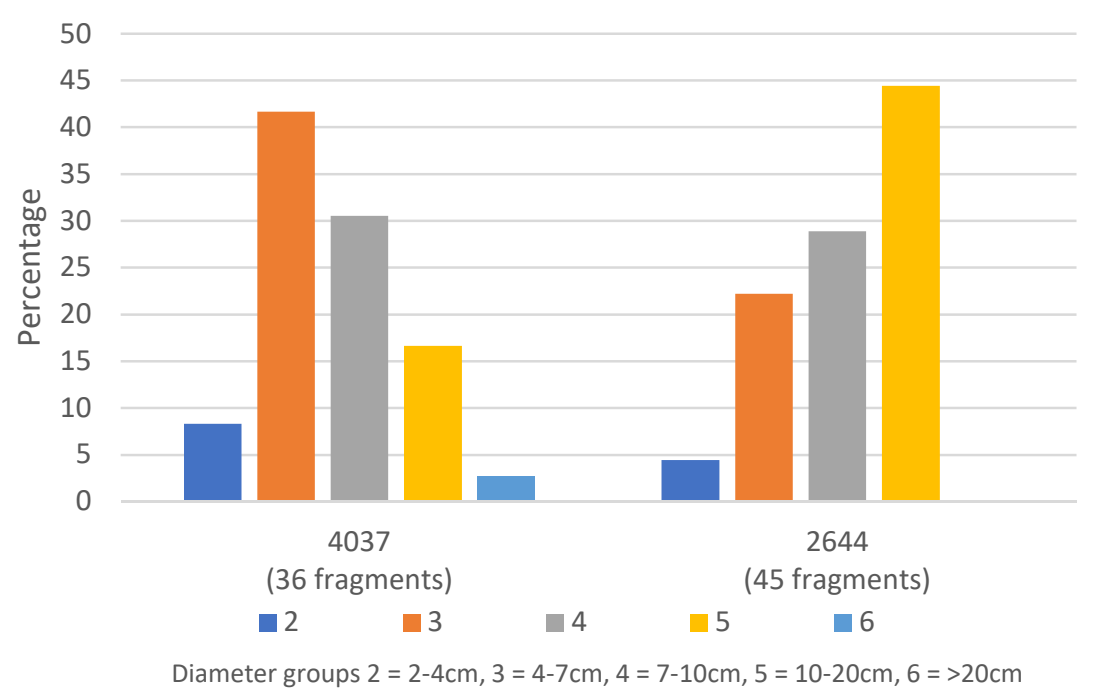


451

452

453

454

455

456

457 4.2.2.2. Sapwood vs Heartwood

458 Sapwood dominates the assemblage with $95.65 \%$ of the fragments (Fig. 12).

459 The small amount of heartwood comes exclusively from the malting oven 460 context 4037.

\section{4.2.2.3. Annual growth}

462 The growth range for the site is between $0.81 \mathrm{~mm}$ and $4.1 \mathrm{~mm}$ (excluding the 463 outliers) with an average of $2.21 \mathrm{~mm}$. The sample from context 2644 has a 464 significantly higher average annual growth rate of $2.65 \mathrm{~mm}$ with a range from $4651.29 \mathrm{~mm}$ to $4.99 \mathrm{~mm}$ and outliers reaching $6.52 \mathrm{~mm}$ (Fig. 13). In contrast the 466 sample from the malting oven context 4037 has a lower growth range of 0.81 $467 \mathrm{~mm}$ to $3.75 \mathrm{~mm}$ with an average annual growth of $1.76 \mathrm{~mm}$. 


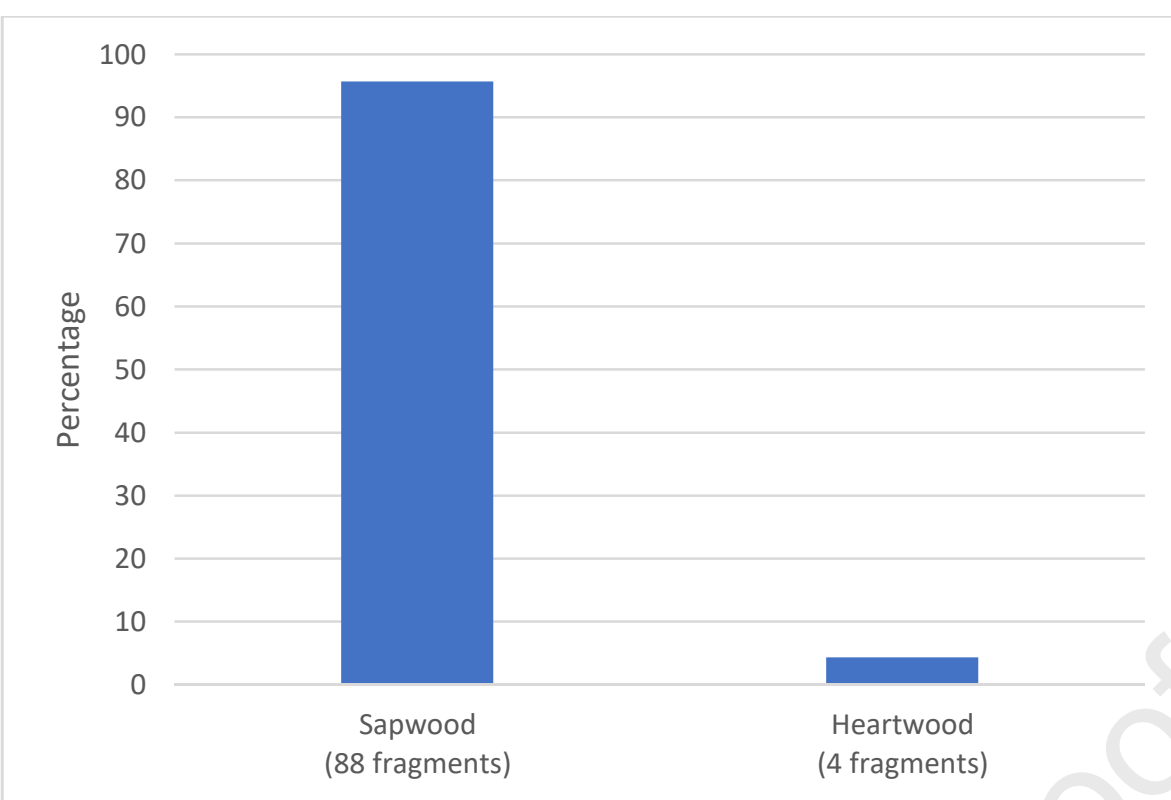

471

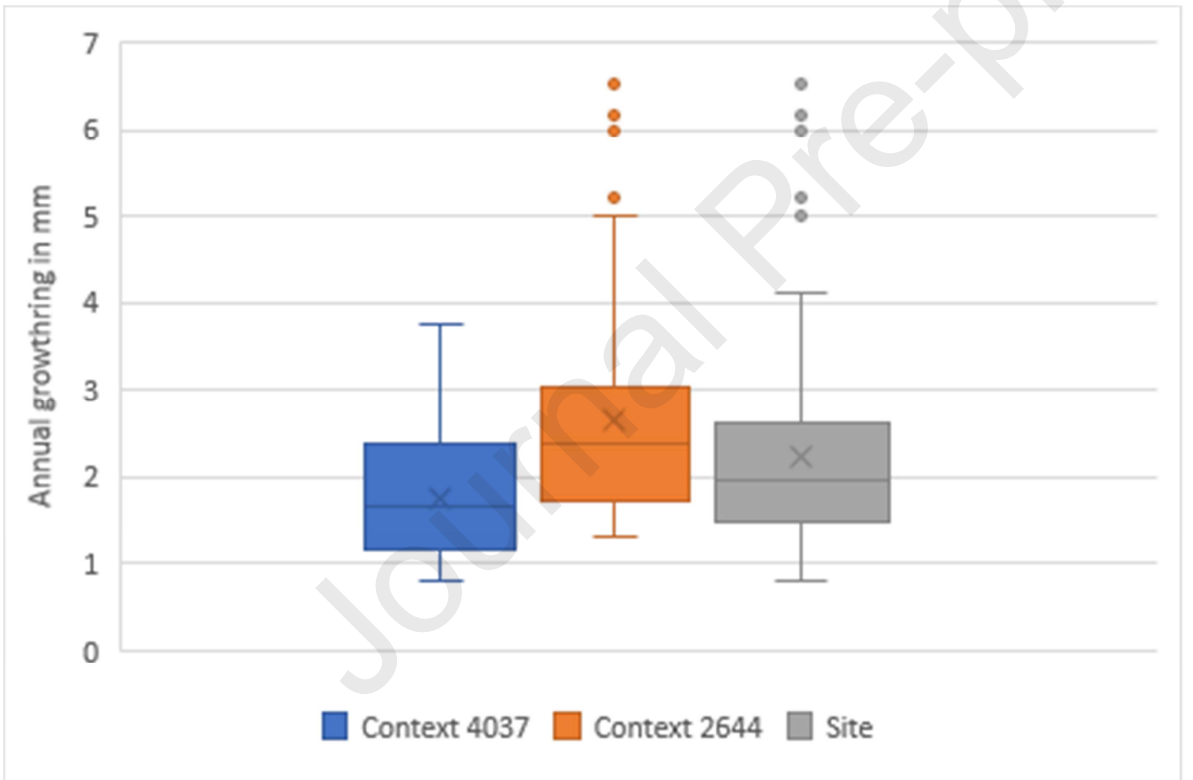

473 Fig. 12. Distribution of charcoal fragments by sapwood and heartwood.

474 Fig. 13. Annual growth ring range by context and overall, for the site.

476 4.2.2.4. Anthraco-typological analysis

477 The combination of these three parameters indicates at a site-wide level the 478 exploitation of fast-growing sapwood (anthraco-groups 2 and 6 ) and slow 479 growing sapwood (anthraco-group 5) representing $88.15 \%$ of the assemblage 480 (Fig. 14). The average diameter of fragments from anthraco-group 2 is $4.93 \mathrm{~cm}$. 481 The maximum diameter is $6.27 \mathrm{~cm}$ and the average growth rate is $2.69 \mathrm{~mm}$. 482 The average diameter of fragments from anthraco-groups 6 is $10.74 \mathrm{~cm}$, the maximum diameter is $17.85 \mathrm{~cm}$ and the average growth rate is $2.59 \mathrm{~mm}$. The 
484 average diameter of fragments from anthraco-group 5 is $10.64 \mathrm{~cm}$, the 485 maximum diameter is $15.23 \mathrm{~cm}$ and the average growth rate is $1.21 \mathrm{~mm}$ (SM. 486 2). This data suggest on one hand the exploitation of young tree trunks less 487 than 20 years old (anthraco-group 2) and on the other hand the exploitation of older trunks over 20 years old (anthraco-group 5 and 6 ) but whose heartwood is under represented with only a few fragments present in anthraco-groups 4 and 8 of context 4037 . The sample from context 2644 (the fill of a post pipe) is dominated by wood that is fast growing sapwood, the majority of which is from anthraco-group 6. The sample from context 4037 (the malting oven) in contrast 493 has a more even spread over groups 1,2,5 and 6 suggesting the use of slow and 494 fast growing young and mature sapwood. Fragments belonging to Anthraco495 group 1 are only found in context 4037 and account for $22.58 \%$ of the sample. 496 The average diameter is $5.72 \mathrm{~cm}$, the maximum diameter is $6.72 \mathrm{~cm}$ and the 497 average annual growth is $1.17 \mathrm{~mm}$. Context 4037 also contains a very small 498 number of fragments from anthraco-group 4 and 8 which represent fast growing 499 heartwood. The diameter of the fragment from anthraco-group 4 is $3.45 \mathrm{~cm}$ and 500 its growth rate is $1.68 \mathrm{~mm}$. The diameter of the fragment from anthraco-group 8 501 is $13.33 \mathrm{~cm}$ and its growth rate is $3.76 \mathrm{~mm}$.

502

503

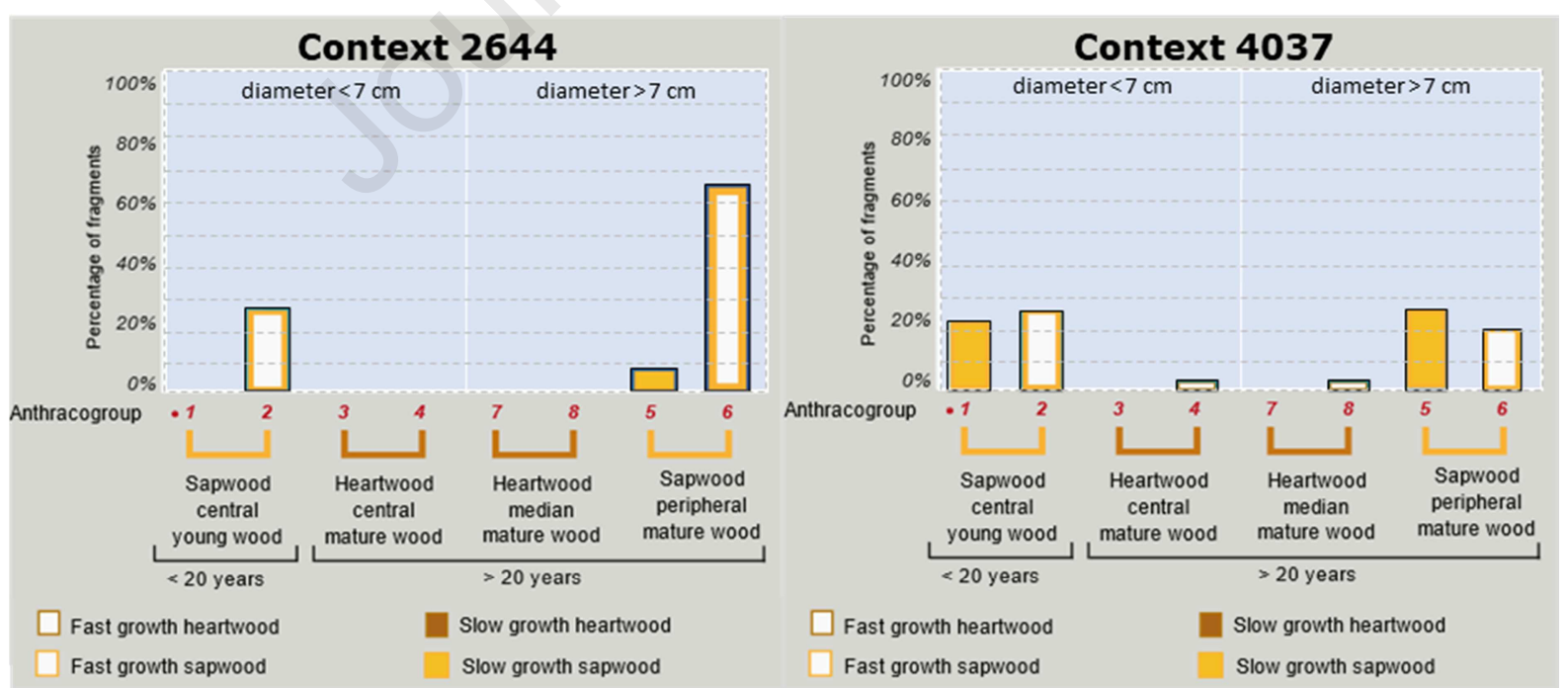

505 Fig. 14. Dendro-anthracological key for the oak from Higham Ferrers sorted into anthraco-groups 
506

507 4.2.3. Flixborough

508

509 4.2.3.1. Wood diameter

510 The diameter range at Flixborough varies between $2-4 \mathrm{~cm}$ and $>20 \mathrm{~cm}$ with the

511 highest number of fragments (29.88\%) belonging to class $10-20 \mathrm{~cm}$, followed by

512 classes $>20$ and $4-7 \mathrm{~cm}$. The least represented class is $2-4 \mathrm{~cm}$. The distribution

513 of diameter classes is not the same from one context to the other. Charcoal from

514 the $10-20$ and $>20 \mathrm{~cm}$ classes dominates in context 3758 , while there is a

515 relatively even spread across classes 4-7, 7-10 and 10-20 cm in context 6136

516 (Fig. $15 \& 16$ ).

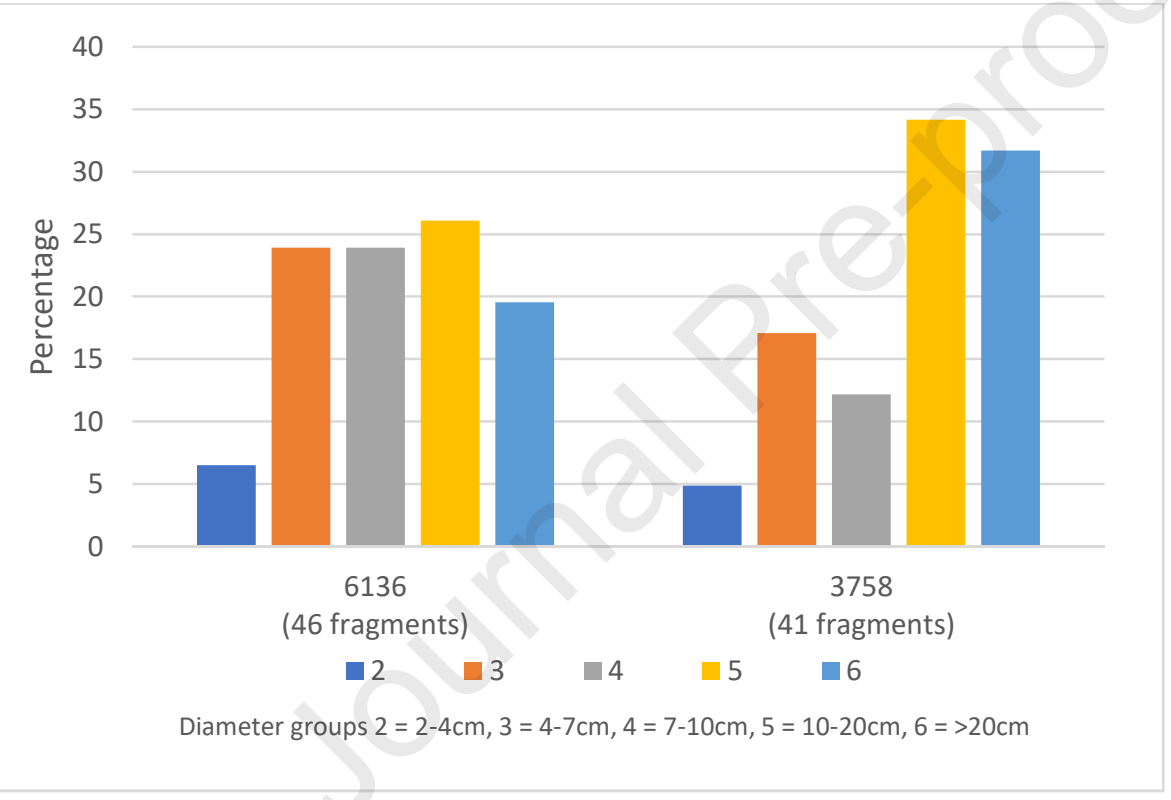




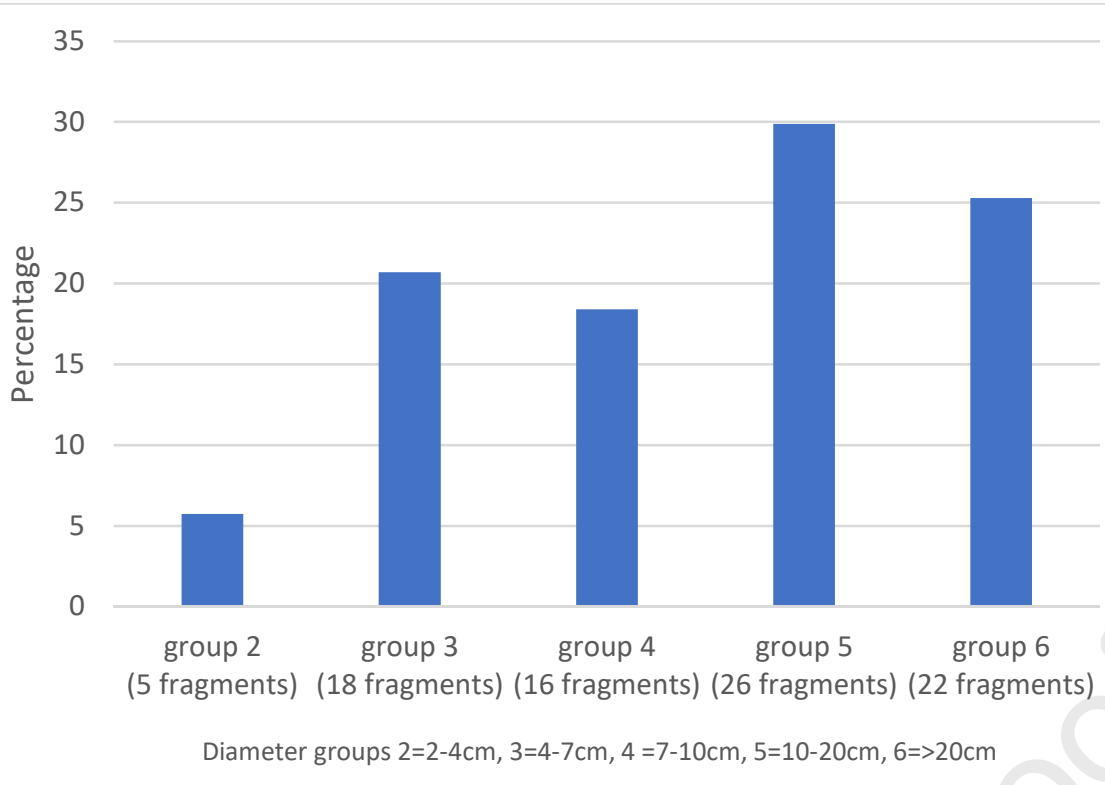

521 Fig. 15. Charcoal fragments in percentages by context and

522 diameter group.

523 Fig. 16. Charcoal fragments in percentages for the site by diameter group

524

525 4.2.3.2. Sapwood vs Heartwood

526 Sapwood dominates the assemblage with $92.85 \%$ of the fragments (Fig. 17).

527 The small amount of heartwood present comes from both contexts.

528

529 4.2.3.3. Annual growth

530 The growth range for the site is between $0.52 \mathrm{~mm}$ and $3.27 \mathrm{~mm}$ (excluding the

531 outliers) with an average of $1.82 \mathrm{~mm}$. Both samples have similar average 532 growth rates with $1.94 \mathrm{~mm}$ for context 3758 and $1.70 \mathrm{~mm}$ for context 6136, 533 although context 3758 has a higher range with growth rates up to $3.81 \mathrm{~mm}$ (Fig. 534 18). 


\section{Journal Pre-proof}

537

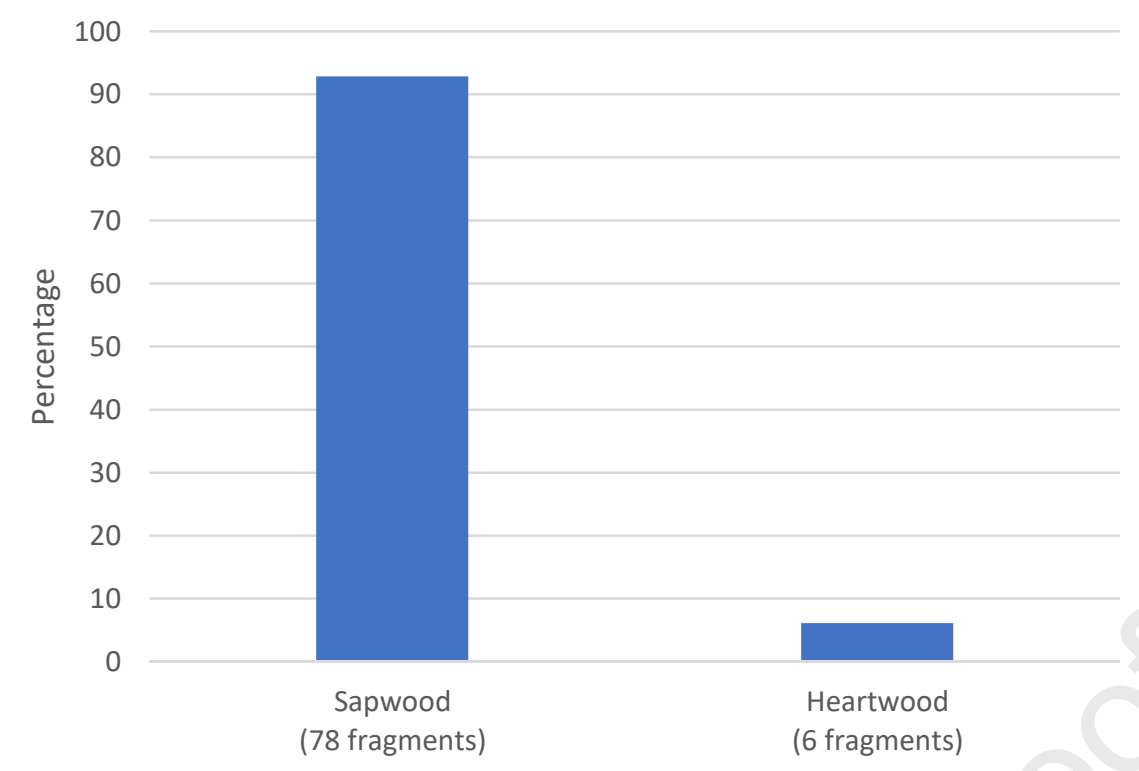

538

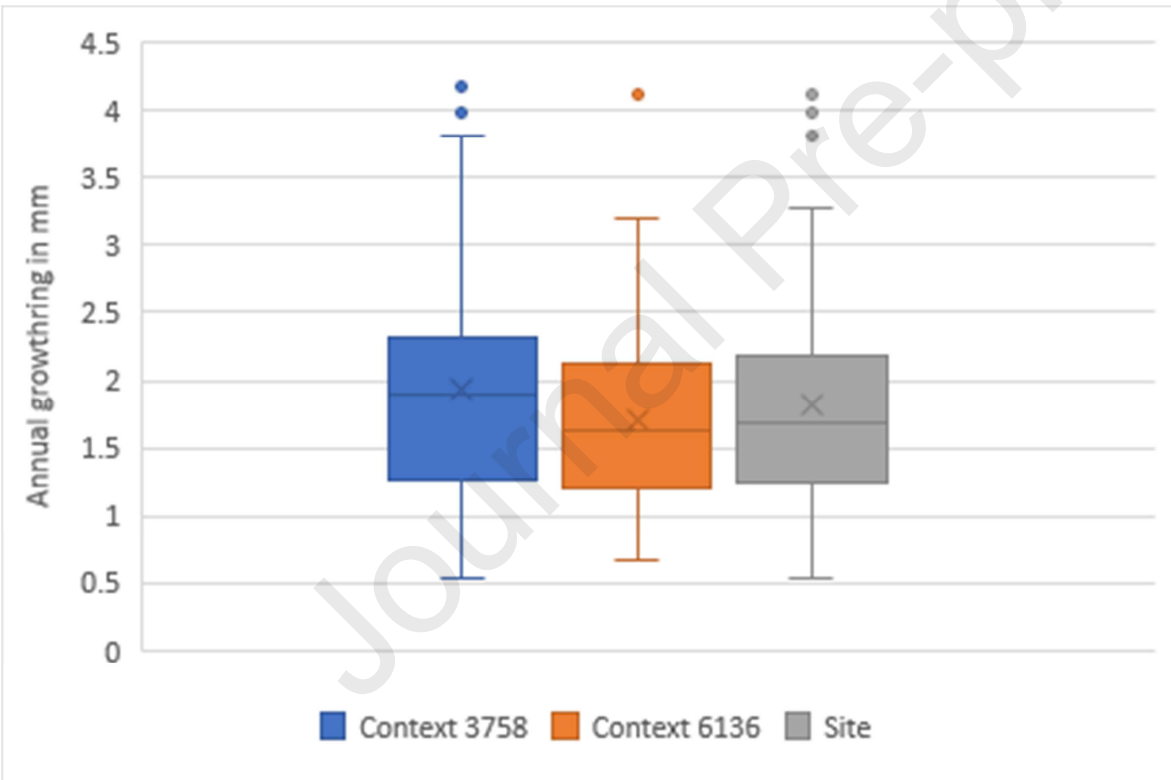

540 Fig. 17. Distribution of charcoal fragments by sapwood and heartwood.

541 Fig. 18. Annual growth ring range by context and overall for the site.

542

543

4.2.3.4. Anthraco-typological analysis

544

545

546

547

548

549 


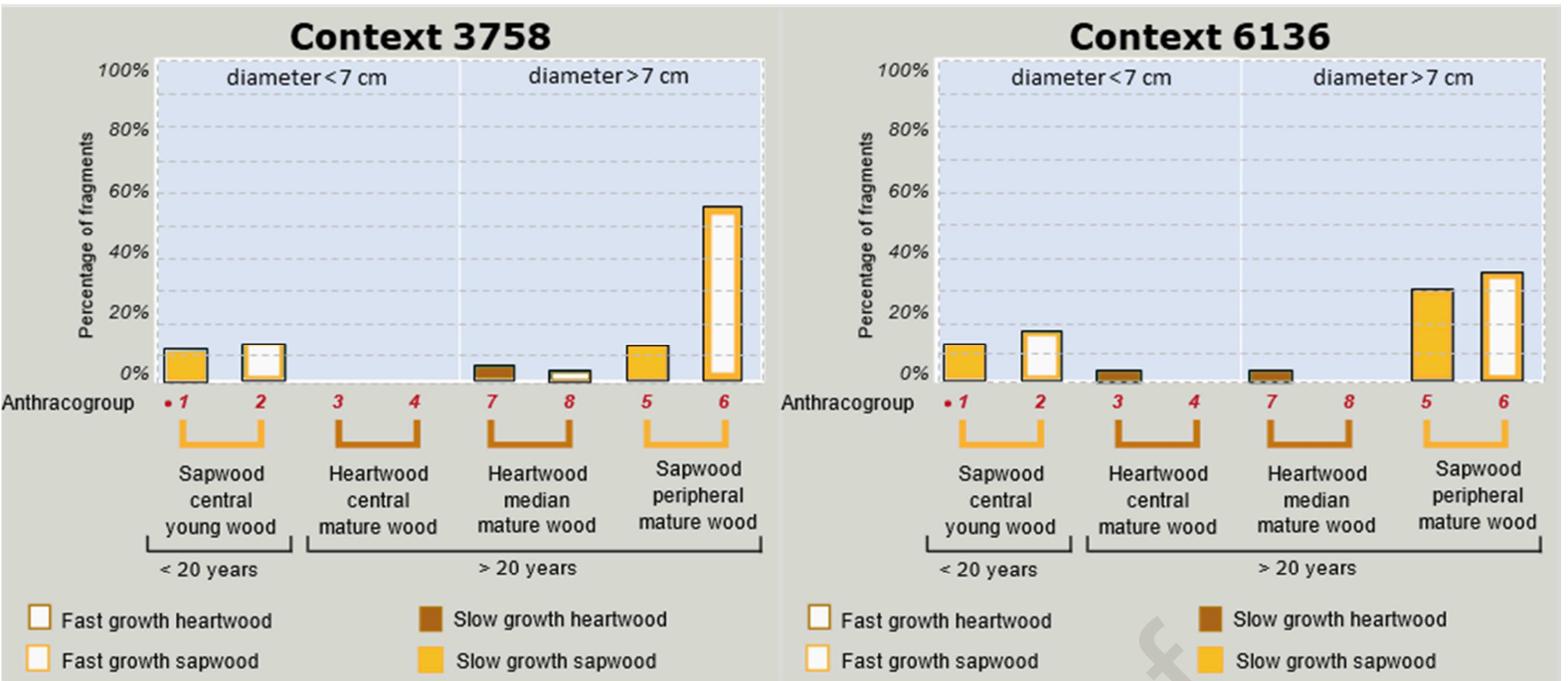

Fig. 19. Dendro-anthracological key for the oak from Flixborough sorted into anthraco-groups

553 The anthraco-typological results of the two contexts are very similar (Fig. 19, 554 see also SM. 3).

555 The combination of these three parameters indicates at a site-wide level the 556 exploitation of fast growing sapwood from the periphery of the trunk over 20 557 years old (anthraco-group 6), representing $44.59 \%$ of the charcoal examined.

558 Slow growing sapwood from wood over 20 years old (anthraco-group 5) 559 represents $20.27 \%$. The average diameter of fragments from anthraco-group 6 560 is $24.02 \mathrm{~cm}$, the maximum diameter is $104.92 \mathrm{~cm}$ and the average growth rate 561 is $2.37 \mathrm{~mm}$. The average diameter of fragments from anthraco-group 5 is 16.88 $562 \mathrm{~cm}$, the maximum diameter is $53.44 \mathrm{~cm}$ and the average growth rate is 1.16 $563 \mathrm{~mm}$. The maximum diameter in group 5 and 6 may be erroneous due to very 564 large outliers within the sample from context 3758. In addition, they are 565 probably unreliable values as the margin of errors can be very important for 566 diameters bigger than $20 \mathrm{~cm}$ (see Dufraisse et al., 2020). The presence of 567 fragments belonging to anthraco-groups 3, 7, 8, 5 and 6 suggest the 568 exploitation of trunks older than 20 years old. Considering the estimated 569 diameters it is likely that heartwood is underrepresented in this assemblage.

570 Anthraco-group 1 represents slow growing sapwood close to the pith and 571 potentially corresponds to branch wood. $12.16 \%$ of the sampled fragments come 572 from anthraco-group 1, these have an average diameter of $4.37 \mathrm{~cm}$, a maximum 573 diameter of $5.56 \mathrm{~cm}$ and an average growth rate of $1.02 \mathrm{~mm}$ a year.

574 The presence of wood from group 2 is nearly similar across the two contexts and 575 represents $16.21 \%$ of the assemblage. Anthraco-group 2 represents fast 
growing sapwood from young trees (less than 20 years old). The average

577 diameter of fragments from anthraco-group 2 is $5.16 \mathrm{~cm}$, the maximum

578 diameter is $6.96 \mathrm{~cm}$ and the average growth rate is $2.36 \mathrm{~mm}$. There are

579 similarities between the two samples for anthraco-group 2 . The average

580 diameter for context 6136 is $5.51 \mathrm{~cm}$ and is $4.68 \mathrm{~cm}$ for context 3758 . The

581 average annual growth rate for context 6136 is $2.28 \mathrm{~mm}$ and for context 3758 is

$582 \quad 2.46 \mathrm{~mm}$.

583

584

585 5. Interpretation of the anthraco-typological data

586 5.1. Dando Close

587

588 The majority of the wood is fast growing sapwood of less than $7 \mathrm{~cm}$ in diameter, 589 followed by fast growing sapwood from the periphery of mature trees of more 590 than $7 \mathrm{~cm}$ in diameter. There is no wood with a diameter over $20 \mathrm{~cm}$. All four 591 contexts reflect a similar pattern that little or no heartwood is present. The 592 majority of the wood is sapwood belonging to anthraco-group 2 suggesting trees 593 that are under 20 years old. There are no standout differences between the 594 three samples from the mid $5^{\text {th }}$ to mid $9^{\text {th }}$ century AD period and the one sample 595 from the mid $9^{\text {th }}$ to $10^{\text {th }}$ century. There are similarities between the composition 596 of the anthraco-groups of contexts 3256 and the later context 3274 . Both are 597 dominated by similar amounts of young sapwood. They also have similar 598 average growth rates of $1.93 \mathrm{~mm}$ and $2.64 \mathrm{~mm}$ respectively. The average 599 diameters are also similar, $4.52 \mathrm{~cm}$ for context 3256 and $3.96 \mathrm{~cm}$ for context 600 3274. It may be postulated that a similar harvest strategy is being practiced, on 601 trees of a similar age and size at two different periods. Context 3274 is believed 602 to come from the short-term deposit related to the burning down of a grain 603 store, therefore the wood may relate to the building's structure. Context 3256 is 604 ambiguous as it is not associated with any structure. As the sample contains 605 branch wood it is unlikely that this is the burning of a single post.

606 Context 3295 (the fill of a post hole in a sunken feature building) is believed to 607 represent a long term deposit and therefore may represent the common harvest 608 strategy for domestic fuel. If so, this represents the harvesting of oak up to 14 $609 \mathrm{~cm}$ in diameter but also that of branch wood. The average growth for the context 
610 is low at $1.66 \mathrm{~mm}$, possibly suggesting the harvesting of wood from dense

611 woodland where light levels are low.

612 Context 3719 (hearth) is believed to represent a short-term deposit. Its

613 anthracological composition is similar to that of context 3295, as are the dendro-

614 anthracological results. This could represent a similar harvesting strategy for

615 domestic fuel.

616 5.2. Higham Ferrers

617 The majority of the wood belongs to fast growing sapwood from the periphery of

618 mature trees. The diameter of the wood is mostly between $4-20 \mathrm{~cm}$ with over

$61995 \%$ of the wood being sapwood. The majority of the wood is in anthraco-group

6206 suggesting the wood came from the outer section of tree trunks over 20 years

621 old. $22.58 \%$ of the fragments from Context 4037 (the malting oven) are in

622 anthraco-group 1. This suggests that some branch wood was used. No charcoal

623 from context 2644 comes from anthraco-group 1. The presence of branch wood

624 in context 4037 could relate to the use of wood trimmed from trees as fuel

625 (Bernard et al, 2006), and could suggest the deliberate addition of branch wood

626 to provide a fast burn at high temperature. The malting oven sample may

627 represent a short-term deposit and therefore could be indicative of the wood

628 selection strategy for the malting process. The earlier context 2644 was

629 exclusively oak and may represent structural wood as it comes from the fill of a

630 post pipe.

631

632

\section{5.3. Flixborough}

634 Both contexts represent the dumping of waste material, believed to be the result 635 of the removal or renovation of buildings at the site. The anthracological 636 assessment shows a dominance of oak but also hazel, ash and alder as 637 secondary taxa. The majority of the wood belonged to fast growing sapwood 638 from the periphery of mature trees, followed by wood from slow growing 639 sapwood from the periphery of mature trees. The majority of the wood was 640 above $10 \mathrm{~cm}$ in diameter. There is very little heartwood present. The majority of 641 the wood is sapwood belonging to anthraco-group 5 and 6, suggesting trees that 642 are over 20 years old. The growth rates are similar between the two periods. 643 However, the size of wood used appears to have increased in the later context 
3758 ( $\mathrm{mid} 9^{\text {th }}$ century) from an average of $18.06 \mathrm{~cm}$ for anthraco-group 6 up to

$64527.90 \mathrm{~cm}$ for group 6 in the later period.

\section{6. Discussion}

648 All three sites show a dominance in the use of deciduous oak. This suggests that oak was likely to have been abundant in the local vicinities. These finding support the evidence from elsewhere in Britain during this period of oak being the primary source of wood for fuel and timber. Similarly, the evidence for secondary taxa of hazel and ash is also in agreement (Smith, 2002, Murphy et al., 2001, Huntley, 2010). The calibre of the wood varies from site to site with Dando Close using the smaller size ranges. The diameter of wood being used is greater at Higham Ferrers and greater still at Flixborough where there is evidence of the use of large trunk wood. The size of wood at Flixborough can be explained by the use in structures rather than as fuel. Whereas at the site of Dando Close and Higham Ferrers contextual information suggests that most of these assemblages are the result of the burning of firewood.

660 The sites of Dando Close and Higham Ferrers are comparable for several 661 reasons. The sites are both rural early medieval settlements, situated in the 662 same region. Both have similar geographic locations set on limestone ridges 663 overlooking the Nene River Valley in a region of sparse woodland. Furthermore, 664 the sampling strategies were similar, and therefore it is possible to compare the 665 results. In the case of Dando Close, the small amount of heartwood present in 666 the samples is significant. In over half these cases this can be explained by most 667 of the charcoal coming from wood that is younger than 20 years old and hence 668 would not have heartwood present. However, this does pose the question of why 669 no heartwood is present in the remaining fragments that are from wood over 20 670 years old. The site of Higham Ferrers also exhibits a similar absence of

671 heartwood. It is unsure why heartwood is underrepresented. It could be a result 672 of differential combustion or preservation. It should also be noted that the 673 sapwood and heartwood of deciduous oak have different physical properties and 674 therefore different parts of the tree may be selected for different purposes, such 675 as industrial fuel, or timber. Other hypothesis are possible as the variation of the 676 age of the duraminisation can depends on intrinsic and extrinsic parameters 677 such as oak species (including hybridization) and environment. 
The annual growth of the wood when separated into anthraco-groups shows that

679 there is similarity between the sites in group 1 and 5 (slow growing sapwood) 680 which may suggest branches growing at similar rates. The fast-growing sapwood 681 of groups 2 and 6 also show similarities between the sites, although fragments in group 6 from Higham Ferrers have slightly larger average ring widths.

684 In the case of Flixborough the sampling strategy (hand collected fragments) was different to the other sites and therefore it is difficult to draw direct comparisons. However, because of the exceptional preservation of large fragments of charcoal, this has provided an excellent opportunity to assess the growth patterns of these trees.

Much of the charcoal rich contexts were believed to derive from the clearance and replacement of buildings. The original assessment of the contexts and structures carried out by Loveluck and Darrah (2007) postulated that if the structural oak timber posts were $25 \mathrm{~cm}$ in diameter, some repair would be needed in the first 20 years and a significant rebuilds every 40 years. If the wood had been seasoned it would last longer, also if heartwood was used it is more resilient to decay and rots more slowly (Loveluck and Darrah, 2007: 5455). Structural assessments found physical evidence of post pads and trenches cut through to accommodate replacement posts (Loveluck and Darrah, 2007: 55). The assessment found that most of the timber remains would have been roundwood of less than $25 \mathrm{~cm}$ in diameter (Loveluck and Darrah, 2007: 55). This is supported by this dendro-anthracological assessment as most of the fragments have an estimated diameter of over $10 \mathrm{~cm}$. Loveluck and Darrah (2007: 55) also state that the wood was sapwood growing at a regular annual rate of up to $2 \mathrm{~mm}$, consistent with trees growing in high forest (a woodland consisting of single stemmed trees growing from seed to their full height). In contrast, the dendro-anthracological assessment of the Flixborough oak showed that $80 \%$ of the fragments analysed have irregular growth patterns, suggesting either climatic or human disturbance to the trees (Fig. 20). Abnormal climatic events such as drought, extreme temperatures and precipitation can cause variations in the annual growth rings (Speer, 2010: 10). Physical damage to a 710 tree, like trimming, grazing, coppicing, pollarding, or removing the crown can

711 lead to the reduction in the width of the annual growth ring (Schweingruber et 712 al., 2006: 113). All of these require cutting the stem or branches of broadleaved 
713 species. The process relies on the plant sprouting from dormant buds or from

714 suckers from the base of the tree (Deforce and Haneca, 2015). Trees that are

715 coppiced have a higher radial growth rate in the first years compared with trees

716 growing from seed. This is due to the large established root system of the

717 coppice stool (Haneca et al., 2005). Some of the fragments analysed from

718 Flixborough show large ring growth close to the pith for the first few years,

719 reducing thereafter.

720

721

722

723

724

725

726 The process of pollarding or trimming oak causes an abrupt reduction in growth

727 resulting in a reduced ring. Late wood is reduced, there is no alteration to the

Fig. 20. Fragment 28 context 3758, showing large initial growth rings. earlywood width in the first year after pollarding. The following two years show reduced earlywood and an overall reduction in the ring width. After this point the growth gradually returns to normal (Haneca et al., 2009). It is possible that some of the fragments that come from trees with large diameters show trends that could be the consequence of pollarding or trimming (Fig. 21). Alternatively, these irregular patterns could relate to the understory being cut at regular intervals. 


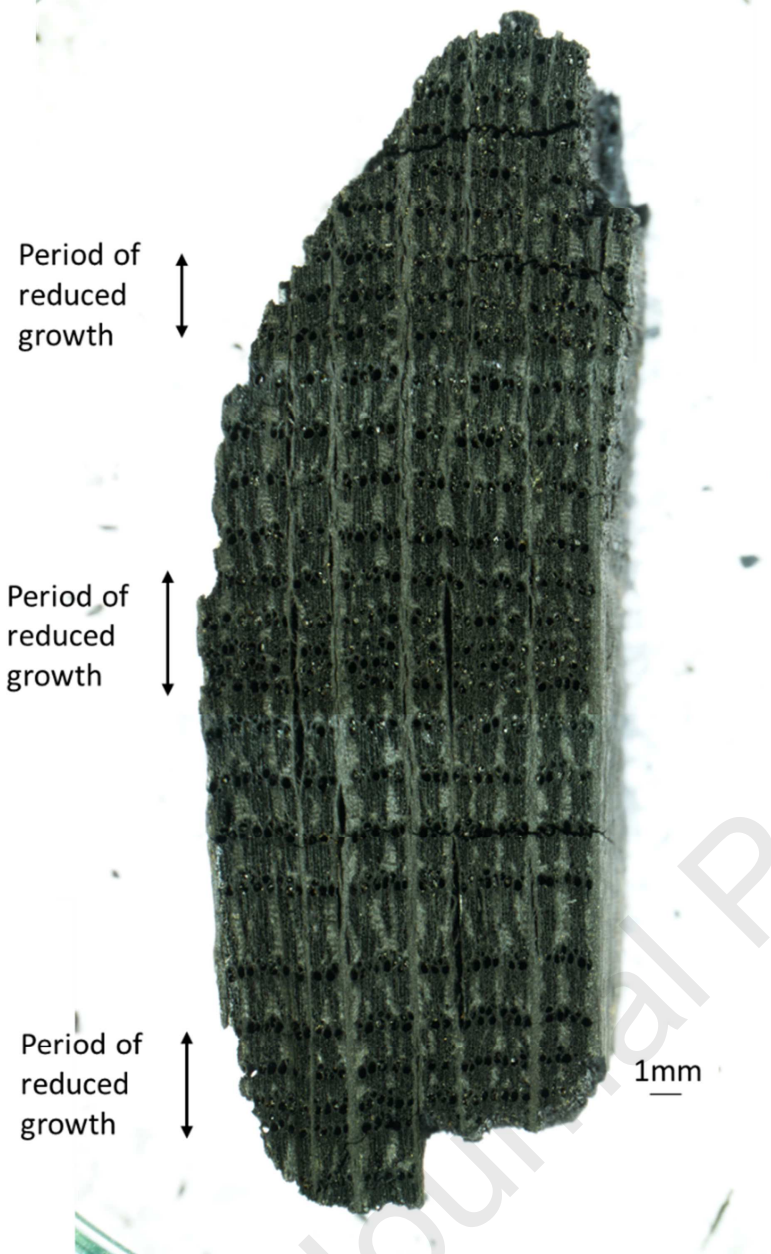

Fig. 21. fragment 10 from context 6136, showing three periods of reduced growth followed by

740 subsequent accelerated growth.

741 It is our hypothesis that a form of woodland management is happening at this

742 site. During the early medieval period, woodland is believed to have been

743 broadly divided into coppice-wood and pasture wood (Rackham 1995:54).

744 Reviewing the evidence provided by the dendro-anthracological assessment, it is 745 unlikely that the wood comes from wood pasture as the average growth rate for 746 a free standing tree would be higher at around 4mm (Rackham 1995: 13).

747 Furthermore the presence of wood from younger trees would not support wood 748 pasture unless they were being protected from grazing animals. One suggestion 749 that would accommodate the findings is that of coppice with standards whereby 750 selected trees would grow to maturity within coppiced woodland. Alternatively, 751 the standards may be having their branches trimmed periodically in a form of 
pollarding. The larger trees are witnessing periodic reduced growth, either as a

753 result of the tree being damaged or as a result of the light level being steadily

754 reduced. Once the canopy is opened up and light levels increase the trees show

755 a growth increase.

756

757 7. Conclusion

758 The aim of this study was to expand the interpretation of the archaeological 759 charcoal assemblages for the three study sites beyond the identification of taxa 760 present and the diversity of the harvested wood. The anthracological analysis 761 showed that deciduous oak was the main taxa being exploited with hazel and 762 ash as secondary taxa. The application of dendro-anthracological tools have 763 shown remarkable results, with data shedding light on the age range of the 764 fragments, their size, growth rate and potential harvesting strategies being 765 employed. The samples from Dando Close provided evidence that the majority of 766 the charcoal came from fast growing sapwood from trees of less than 20 years old, with an estimated diameter of between $2-7 \mathrm{~cm}$. The charcoal from the samples from Higham Ferrers represent a majority of fast-growing sapwood from trees older than 20 years and with an estimated diameter of between 4 $20 \mathrm{~cm}$. The samples from Flixborough show that the majority of the charcoal came from fast growing sapwood from large trunks over 20 years old and of between $10 \mathrm{~cm}$ and in excess of $20 \mathrm{~cm}$ in diameter. The evidence from all three sites exhibit the lack of heartwood present. The irregular growth patterns visible on the large fragments from Flixborough suggest episodic disruption to the growth rate of the wood, which we postulate is being caused by a woodland management regime such as pollarding or the management of coppice with 777 standard.

To take this interpretation further the dendro-anthracological sampling of the 780 three sites needs to be increased so as to create a more expansive dataset. 781 Additionally, it would be desirable to apply the dendro-anthracological tools to 782 the next most abundant taxa, those of hazel and ash. This would allow for a 783 wider interpretation of harvesting strategies and woodland management. 
Acknowledgements

787 This study represents part of the objectives of R Francis' PhD thesis Agriculture,

788 Horticulture, Woodland Management and Society in England, c. AD400 - 1100:

789 integrated perspectives. (From archaeobotany, dendroanthracology, textual 790 sources and experimental archaeology). R Francis is funded by a PhD grant from 791 the Arts and Humanities Research Council Funding. AHRC funding through the 792 Midlands4Cities Doctoral Training Partnership. The authors acknowledge the 793 curators of the archaeobotanical material Rebecca Nicholson of Oxford 794 Archaeology, James Rackham of Environmental Archaeology Consultancy and 795 Rose Nicholson of the North Lincolnshire Museum and thank them for the loan of 796 the charcoal assemblages analysed.

797 The authors acknowledge M. Lemoine (CNRS) assistance in dendro798 anthracological data curation.

799 The authors would also like to thank the guest editor, Eleni Asouti, for the 800 invitation to participate in this special issue.

801

802 Formatting of funding sources

803 This work was supported by the Arts and Humanities Research Council Funding. 804 AHRC funding through the Midlands4Cities Doctoral Training Partnership [grant 805 numbers M3C1299, M3C1509]

806

807 Authorship contribution statement

808 Robert Francis: Dendro-anthracological methodology, Anthracological and 809 dendro-anthracological data curation, Writing - original draft, Writing - review \& 810 editing, Funding acquisition.

811

812 Alexa Dufraisse: Dendro-anthracological methodology, participation to Writing 813 original draft, Writing - review \& editing

\section{Bibliography:}

818 Ashworth, H., Semmelmann, K., 2003. Land at Dando Close Archaeological 819 Assessment Report. Heritage Network, Baldock. 
821 Asouti, E., Austin, P., 2005. Reconstructing Woodland Vegetation and Its

822 Exploitation by Past Societies, Based on the Analysis and Interpretation of

823 Archaeological Wood Charcoal Macro-Remains. Environmental Archaeology. 10.

824 1-18.

825 Bernard, V., \& Renaudin, S. \& Marguerie, D. 2006. Evidence of trimmed oaks 826 (Quercus sp.) in north western France during the early middle ages. Charcoal 827 Analysis: New Analytical Tools and Methods for Archaeology. 103-108.

828

829 Braadbaart, F., \& Poole, I. 2008. Morphological, chemical and physical changes 830 during charcoalification of wood and its relevance to archaeological contexts. 831 Journal of Archaeological Science, 35(9), 2434-2445.

832

833 British Geological Survey, Geology of Britain 2020, viewed 25 July 2020,

834 <http://mapapps.bgs.ac.uk/geologyofbritain/home.html>

835

836 Chabal, L., L. Fabre, J.-F. Terral, and I. Théry-Parisot 1999 "L'anthracologie," in

837 La botanique. Edited by C. Bourquin-Mignot, J.-E. Brochier, L. Chabal, et al., pp. 838 43-104. Paris: France.

839

840 Collop, C., 2011. Lincolnshire Biodiversity Action Plan 2011-20. 3rd edition.

841 Greater Lincolnshire Nature Partnership.

842

843 Crew, P. Mighall, T. 2013. The fuel supply and woodland management at a 14th

844 century bloomery in Snowdonia: a multi-disciplinary approach. The World of 845 Iron. Proceedings of a Conference at the Natural History Museum 2009. 473846482.

847

848 Dark, P., 2000. The Environment of Britain in the First Millennium A.D. London, 849 Duckworth.

850

851 Deforce, K., Haneca, K., 2015. Tree-ring analysis of archaeological charcoal as a 852 tool to identify past woodland management: The case from a 14th century site 853 from Oudenaarde (Belgium). Quaternary International. 366. 70-80. 
855 Dufraisse A., S. Coubray, O. Girardclos, N. Nocus, M. Lemoine, J.-L. Dupouey, D. 856 Marguerie (2018a). Anthraco-typology as a key approach to past firewood 857 exploitation and woodland management reconstructions. Dendrological reference 858 dataset modelling with dendro-anthracological tools. Quaternary International, 859 Vol. 463, Part B: 232-249 https://doi.org/10.1016/j.quaint.2017.03.065

860

861 Dufraisse A., S. Coubray, O. Girardclos, A. Dupin, M. Lemoine (2018b). 862 Contribution of tyloses quantification in earlywood oak vessels to archaeological 863 charcoal analyses: estimation of a minimum age and influences of physiological 864 and environmental factors Quaternary International Vol. 463, Part B: 250-257 865 https://doi.org/10.1016/j.quaint.2017.03.070

866

867 Dufraisse A., Bardin J., Picornell-Gelabert LI., Coubray S., Garcia-Martinez M.S., 868 Lemoine M., Vila Moreiras S. 2020. Pith location tool and wood diameter 869 estimation: validity and limits tested on seven taxa to approach the length of the 870 missing radius on archaeological wood and charcoal fragments. Journal of 871 Archaeological Science Reports, X-XX.

872 https://doi.org/10.1016/j.jasrep.2019.102166

873

874 Forestry Commission, National Forest Inventory 2020, viewed 25 July 2020

875 http://data-forestry.opendata.arcgis.com/datasets/

876

877

878 Gale, R. M O. 2007. Appendix 3: charcoal. Proceedings of the Hampshire Field 879 Club \& Archaeological Society. Vol 62, pp. 67-68.

880

881 Gearey, B., Richer, S., 2017. From Rackham to REVEALS: Reflections on 882 Palaeoecological Approaches to Woodland and Trees. Environmental 883 Archaeology. 23. 286-297.

884

885 Hall, A. 2000. Technical report: Plant remains from excavations at Flixborough, 886 N. Lincolnshire (site code: FLX89). Reports from the Environmental Archaeology 887 Unit, York. 
889 Hall, A. and Kenward, H. 2004. Setting people in their environment: plant and 890 animal remains from Anglo-Scandinavian York. In: Aspects of Anglo-

891 Scandinavian York. The Archaeology of York . Council for British Archaeology,

892 York, UK, pp. 372-426.

893

894 Haneca, K., Van Acker, J., Beeckman, H., 2005. Growth trends reveal the forest 895 structure during Roman and Medieval times in Western Europe: a comparison 896 between archaeological and actual oak ring series (Quercus robur and Quercus 897 petraea). Annals of Forest Science, 62(8). 797-805.

898

899 Haneca, K., Cufar, K., Beeckman, H., 2009. Oaks, tree-rings and wooden 900 cultural heritage: A review of the main characteristics and applications of oak 901 dendrochronology in Europe. Journal of Archaeological Science, 36. 1-11.

902

903

904 Hardy, A., Charles, B.M., Williams, R.J., 2007. Death and taxes. The archaeology 905 of a Middle Saxon estate centre at Higham Ferrers, Northamptonshire. Oxford 906 Archaeology Monographs 4.

907

908 Hather, J ., 2000. The identification of the northern European woods. Archetype 909 publications, London.

910

911 Hazell, Z., Crosby, V., Oakey, M., and P, Marshall. 2017. Archaeological

912 investigation and charcoal analysis of charcoal burning platforms, Barbon,

913 Cumbria, UK. Quaternary International, Volume 458, 178-199.

914

915 Hooke, D., 2010. Trees in Anglo-Saxon England. Boydell Press, Woodbridge.

917 Huntley, J P., 2010. A Review of Wood and Charcoal Recovered from 918 Archaeological Excavations in Northern England, Res Dept Rep 68/2010, English 919 Heritage, Portsmouth.

921 Leney, L., Casteel, R, W., 1975. Simplified procedure for examining charcoal 922 specimens for identification. Journal of Archaeological Science, 2. 153-59. 
924 Loveluck, C.P., 2007. Rural Settlement, Lifestyles and Social change in the later

925 first millennium AD. Anglo-Saxon Flixborough in its wider context. Excavations at

926 Flixborough, Volume 4, Series ed. C.P. Loveluck, Oxbow Books, Oxford.

927

928 Loveluck, C., Darrah, R., 2007. The Built Environment: The Buildings, Aspects of

929 Settlement Morphology and the Use of Space' in Loveluck, C., (ed.). Rural

930 Settlement, Lifestyle and Social Change in the Later First Millennium AD: Anglo-

931 Saxon Flixborough in its Wider Context, Excavations at Flixborough 4. Oxbow,

932 Oxford.

933

934 Ludemann, T. 2008. Experimental charcoal burning with special regard to

935 anthrocological wood diameter analysis. In Charcoals from the Past: Cultural and

936 Palaeoenvironmental Implications, G. Fiorentino, and D. Magri (eds). British

937 Archaeological Reports, International Series 1807, 147-157.

938

939 Marguerie, D., Hunot, J.-Y. 2006. Charcoal analysis and dendrology: data from

940 archaeological sites in north-western France, Journal of Archaeological Science.

941 34. 1417-1433.

942

943 Met Office, Climate averages 2020, viewed 25 July

944 2020,<https://www.metoffice.gov.uk/research/climate/maps-and-data/uk-

945 climate-averages/>

946

947 Moffett, L. C., 2007. Charred plant remains in Hardy, A., Charles, B.M., Williams, 948 R.J., Death and taxes. The archaeology of a Middle Saxon estate centre at 949 Higham Ferrers, Northamptonshire. Oxford Archaeology Monographs 4.

950

951 Murphy, P., Hillam, J., Groves, C., 2001. Review of wood and macroscopic wood 952 charcoal from archaeological sites in the west and east midland regions and the 953 east of England. Centre for Archaeology Reports 23/2001: 54.

954

955 Nelle, O, 2002. Charcoal burning remains and forest stand structure - examples

956 from the Black Forest (south-west Germany) and the Bavarian Forest (south-

957 east Germany). In Charcoal Analysis: methodological approaches, 
958 palaeoecological results and wood uses, S. Thiébault (ed.). British Archaeological

959 Reports International Series 1063, 201-208

960

961 Northamptonshire County Council 2020. Biodiversity Action Plan 2015-2020

962 viewed 25 July 2020

963 https://www3.northamptonshire.gov.uk/councilservices/environment-

964 andplanning/planning/planning-policy/archaeology-biodiversity-

965 andlandscape/documents/PDF\%20Documents/Northamptonshire\%20BAP\%2020

966 15-2020.pdf

967

968 Paradis-Grenouillet, S., Dufraisse, A., 2018. Deciduous oak/chestnut: Differential 969 shrinkage of wood during charcoalification? Preliminary experimental results and 970 implications for wood diameter study in anthracology. Quaternary International. $971463,258-267$.

972

973 Rackham, J. , 2003. Ecofact assemblage. In Ashworth, H., Semmelmann, K.,

974 Land at Dando Close Archaeological Assessment Report. Heritage Network, 975 Baldock.

976

977 Rackham, O., 1994. Trees and Woodland in Anglo-Saxon England: The 978 Documentary Evidence' in Rackham, J., (ed) Environment and Economy in 979 Anglo-Saxon England (Council for British Archaeology Report 89). York: Council 980 for British Archaeology, pp. 7-12.

981

982 Rackham, O., 1995. Trees and woodland in the British landscape. Weidenfeld 983 and Nicholson, London.

984

985 Rackham, O., 2006. Woodlands. Collins. London.

986

987 Robinson, M. 1997. Charred plant remains from a Medieval pottery kiln. In The 988 excavation of two medieval pottery kiln sites and two sections through the 989 London-Lewes Roman road at Clacket Lane, near Titsey, 1992. Surrey 990 Archaeological Collections, 84, 1-87. 
992 Schweingruber, F.H., 1982. Microscopic wood anatomy, second edition. F Fluck993 Wirth, Teufen.

994

995 Schweingruber, F.H., Börner, A., Schulze, E.-D., 2006. Atlas of woody plant 996 stems. Evolution, structure, and environmental modifications. Springer-Verlag, 997 Berlin.

998

999 Smith, W., 2002. A review of archaeological wood analyses in southern England. 1000 English Heritage Research Department, Swindon.

1001

1002 Speer, J.H., 2010. Fundamentals of Tree-Ring Research. University of Arizona 1003 Press, Tucson.

1004

1005 Thompson, G., Francis, R., 2007. Charcoal. In Hardy, A., Charles, B.M., Williams, 1006 R.J. Death and taxes. The archaeology of a Middle Saxon estate centre at 1007 Higham Ferrers, Northamptonshire. Oxford Archaeology Monographs 4. 


\section{Declaration of interests}

$\bigotimes$ The authors declare that they have no known competing financial interests or personal relationships that could have appeared to influence the work reported in this paper.

$\square$ The authors declare the following financial interests/personal relationships which may be considered as potential competing interests: 